\title{
Current and Future Diagnostic Tests for Ebola Virus Disease
}

\author{
Bharti Singh, Advaita Ganguly, Hoon H Sunwoo \\ Faculty of Pharmacy and Pharmaceutical Sciences, University of Alberta, 11361 - 87 Avenue, Edmonton, Alberta, \\ Canada T6G 2E1
}

Received, September 16, 2016; Accepted, December 15, 2016; Published, December 20, 2016

\begin{abstract}
Purpose. Ebola virus disease (EVD) is a major public health concern with a high mortality rate in infected individuals. Outbreaks of Ebola have been widespread - there is no rapid, sensitive, specific, and affordable diagnostic test for the virus, nor there is any treatment for the disease. Overlapping symptoms of other endemic diseases, such as malaria and cholera, make it difficult to diagnose EVD. For clinical management, outbreak investigation, and proper surveillance, EVD requires a detection system, which should be fast, sensitive, specific, efficient, affordable, and user-friendly with in-country staff. In this review, we discuss the current diagnostics available for Ebola screening, along with the limitations and key improvements necessary for a more robust system to facilitate efficient management in case of another major outbreak.
\end{abstract}

Keywords - Ebola virus, detection system, outbreak, diagnostic tests

This article is open to POST-PUBLICATION REVIEW. Registered readers (see "For Readers") may comment by clicking on ABSTRACT on the issue's contents page.

\section{INTRODUCTION}

Ebola virus disease (EVD), also known as Ebola hemorrhagic fever, is caused by the Ebola virus (EBOV) which is a filovirus containing a nonsegmented, filamentous, negative-sense, and singlestranded RNA genome $(19 \mathrm{~kb})$. The Filoviridae family members are among the most lethal human viral pathogens in the world. There are three filovirus genera: Marburgvirus, Cuevavirus, and EBOV. Marburgvirus species consist of Marburg virus (MARV) and Ravn virus (RAVV). Cuevavirus includes a single species, Lloviu virus (LLOV). Ebola virus members consist of Zaire EBOV (ZEBOV), Bundibugyo EBOV (BEBOV), Sudan EBOV (SEBOV), Tai forest EBOV (TAFVformally known as CIEBOV or Côte d'Ivoire EBOV) and Reston EBOV (REBOV) (1, 2), all named after their countries of origin, except Reston, which was from the Philippines (3) (Figure 1). Among the different EBOV species, ZEBOV is the most virulent pathogen, resulting in high mortality rates of $85-95 \%$ in infected populations $(4,5)$. Among the eight filovirus species, six (ZEBOV, BEBOV, SEBOV, TAFV, MARV, and RAVV) are known to cause disease in humans (6). There are no drug and vaccine available in the market for the treatment and prevention of EVD although they are in the developmental stage. According to the report of World Health Organization (WHO) in 2014, Greater than 2,400 people have died from EVD in recent months and approximately 4,700 people have been infected (7). Once the person is infected with EVD then there are very few chances of survival, and also the disease can be transmitted through the body fluids of EVD patient to a healthy person. The nosocomial transmission among health care workers and EVD patients represents potential risk for outbreak amplification. These findings highlight the great importance of infection control in dedicated isolation facilities as well as in treatment centers where undifferentiated patients with fever and nonspecific symptoms were admitted (8).

To manage the spread of EVD there are diagnostic methods available that are based on viral RNA detection by PCR (9), antibody detection assays (10), or antigen detection assays (11) - all of which are expensive, time consuming, and requiring a sophisticated infrastructure (12).

Correspondence Author: Hoon H. Sunwoo, PhD, Faculty of Pharmacy and Pharmaceutical Sciences, University of Alberta, 3-142H Katz Group Centre for Pharmacy and Health Research, 11361 - 87 Avenue, Edmonton, Alberta, Canada T6G 2E1. E-mail: hsunwoo@ualberta.ca. Phone: 1-780-492-0547 


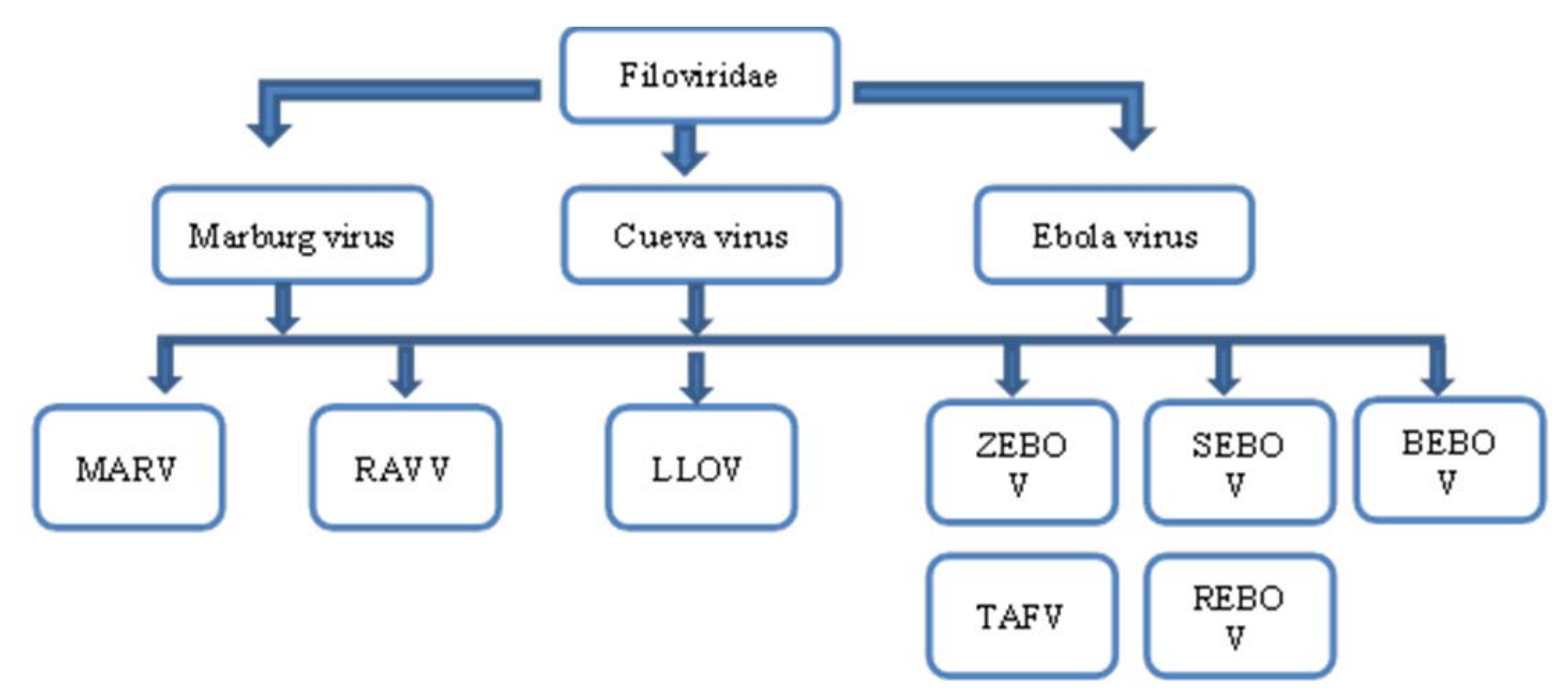

Figure 1: Flow chart of Filoviridae family. Three genus - Marburg virus, Cuevavirus and Ebola virus with species as MARV: Marburgvirus, RAVV: Ravn virus, LLOV: Lloviu virus, ZEBOV: Zaire Ebola virus, SEBOV: Sudan Ebola virus, BEBOV: Bundibugyo Ebola virus, TAFV: Tai forest Ebola virus and REBOV: Reston Ebola virus.

This review focuses on the latest epidemiology, immunology, pathology, and diagnostic tests available, as well as the improvements to current diagnostics necessary to curb the spread of EBOV filoviruses. Updates on existing efforts and procedures of efficient diagnostic assessment of Ebola virus diseases have been discussed. We have assessed in great detail the merits and demerits of each procedure highlighting the detection limits and the associated cost of analysis, which is crucial in endemic regions wherein exists severe resource constraints. The potential use of new diagnostic reagents and novel platforms for developing better screening measures has been discussed for the first time. The review also suggests newer measures to increase efficiency, lowering costs and reducing screening time of prevailing diagnostics as well as the ones being developed to address the delays in assessment as well as better management during an outbreak.

\section{EPIDEMIOLOGY OF EBOLA VIRUS}

The first documented outbreak of the EBOV occurred in 1976 at Yambuku Mission Hospital, Northern Zaire, and caused 280 deaths. This outbreak of ZEBOV (13) was followed by another outbreak in Sudan-by EBOV subtype SEBOV. EBOV outbreaks continued to occur, affecting mostly Sub-Saharan African countries (Zaire,
Sudan, Côte d'Ivoire, Republic of Congo, Gabon, and Uganda). In these early cases, mortality rates varied according to age and sex; for children it was $44 \%$, whereas for teenagers and adults it was $39 \%$ and $56 \%$, respectively. In the male population, mortality was $56 \%$, and in the female population, it was $48 \%$ (14).

After an 18 year "silent phase," the EVD reemerged in 1995 in northern Gabon and the Democratic Republic of Congo (15). Since then, four EBOV outbreaks occurred in Gabon, the Republic of Congo, the Democratic Republic of Congo, and Sudan from 2001 to 2005. In 2007, a new virus subtype, BEBOV (Bundibugyo Ebola Virus), was isolated from 149 infected people in Uganda and resulted in 37 deaths. (16, 17). In 2012 and 2013, outbreaks of the Sudan EBOV in Uganda affected 17 people, resulting in 7 deaths (18). EBOV cases peaked from November 2015 to May 2016 , when there were 28,616 cases of infection and 11,310 deaths reported worldwide (19).

The outbreak of 2014, the largest single outbreak of EVD in history, was widely spread with higher fatality rates in West African countries. As of September 14, 2014, there were 4,507 confirmed and probable cases and 2,296 deaths reported in five African countries (Sierra Leone, Guinea, Liberia, Nigeria, and Senegal) $(20,21)$. The breakdown of the 2014 EVD-confirmed cases and deaths was as follows: 3,814 cases with 2,544 
deaths in Guinea; 10,678 with 4,810 deaths in Liberia; and 14,124 with 3,956 deaths in Sierra Leone (22) (Table 1, (23)).

Table 1. Statistics of Ebola disease in population

\begin{tabular}{|c|c|c|c|}
\hline Country & $\begin{array}{c}\text { Case } \\
\text { definition }\end{array}$ & $\begin{array}{c}\text { Cumulative } \\
\text { cases }\end{array}$ & $\begin{array}{c}\text { Cumulative } \\
\text { deaths }\end{array}$ \\
\hline \multirow[t]{3}{*}{ Guinea } & Confirmed & 3351 & 2083 \\
\hline & Probable & 453 & 453 \\
\hline & Total & 3804 & 2536 \\
\hline \multirow[t]{4}{*}{ Liberia } & Confirmed & 3151 & $t$ \\
\hline & Probable & 1879 & $t$ \\
\hline & Suspected & 5636 & $t$ \\
\hline & Total & 10,666 & 4806 \\
\hline \multirow{4}{*}{$\begin{array}{l}\text { Sierra } \\
\text { Leone }\end{array}$} & Confirmed & 8704 & 3589 \\
\hline & Probable & 287 & 208 \\
\hline & Suspected & 5,131 & 158 \\
\hline & Total & 14,122 & 3955 \\
\hline \multirow[t]{4}{*}{ Total } & Confirmed & 15,221 & $t$ \\
\hline & Probable & 2622 & $t$ \\
\hline & Suspected & 10,767 & $t$ \\
\hline & Total & 28,610 & 11,308 \\
\hline
\end{tabular}

Although EVD is prevalent in African countries, it is also being spread to developed countries, due to emigration and travel. In September 2014, the Centers for Disease Control confirmed a case of Ebola in the United States in a person who traveled to Dallas, Texas from Liberia. On October 23, 2014, the New York City Department of Health and Mental Hygiene reported a case in which a medical aid worker was infected with Ebola when he returned from Guinea after treating Ebola patients (24). On January 9, 2015, six people from West African countries affected by Ebola were granted visas for Canada. Upon arrival, they were kept under surveillance for 21 days, as the incubation period of EBOV is 2-21 days (25).

\section{Disease Onset and Mortality by Age Group}

The most recent EVD epidemic in Africa has caused ailments and death in various age groups, ranging from newborn children to older populations. In January 2015, 79\% of diagnosed patients were 16 years of age or older in West
African countries. The time of onset of symptoms varies with different age groups. Children less than 1 year of age first exhibit the symptoms of disease on day 6, whereas the 10-15 year age group show disease onset on day 9. However, the fatality rate in children less than one year of age was $90 \%$, whereas it was $50 \%$ in $10-15$ years of age group. The older population ( +45 years) showed a $70 \%$ death rate. When the statistical analysis was done for EVD among hospitalized children and adolescents in northern Uganda, it was observed that 90 out of the 218 confirmed EVD cases by national laboratory were children and adolescents with a case fatality rate of $40 \%$. The mean age observed was 8.2 years \pm SD 5.6 with a range of 16.99 years $(8,26,27)$. In 2014, WHO team notified that the majority of EVD patients in Guinea outbreak are 16 to 45 years of age $(49.9 \%$ male), and the case-fatality rate was $70.8 \%$ among the individuals with known clinical outcome of infection. The period of infection, signs, symptoms, and incubation period (12 days) is very much comparable to the previously reported outbreaks of EVD (21).

\section{Transmission}

EBOV needs a host cell to replicate and augment virulence. The virus is thought to exist in a reservoir host, with bats, especially the Epomops franqueti, Myonycteris torquata, and Hypsignathus monstrous species of fruit bats, thought to carry and spread EBOV. The transmission of EBOV from natural reservoir to humans is not very clear and under study, although, it is believed that EBOV infection in humans directly from fruit bats is possible because these animals are eaten and consumed by local people living in the outbreak regions. (28-30). The transmission of the virus among humans is through direct contact with body fluids (saliva, urine, blood, or semen) or organ transplantation from an EVD-infected individual $(31,32)$, and the primary routes of EBOV entry are via the conjunctiva of the eye, mucous membranes, and skin lesions (33). EVD transmission may also occur when a person comes in contact with objects such as needles contaminated with the fluids of EVD infected patients (34). Thus, medical staffs are at high risk of contracting EBOV if proper hygiene and safety procedures are not followed. 


\section{Genome Organization}

EBOV has an RNA genome of $19 \mathrm{~kb}$. The EBOV RNA itself is not infectious, as verified by fluorescent focus-forming assay (35). Gene order is conserved in all filoviruses as: 3' - leader - NP VP35 -VP40 - sGP/GP - VP30 - VP24 - L - trailer 5 ' $(36,37)$. The untranscribed regions (leader and trailer) are partially complementary to each other, a common feature among the order Mononegavirales (38). These untranscribed regions contain the signals necessary for replication, transcription, and packaging of the viral RNA genome, as well as replication of the antigenomic viral RNA (39). Start and stop signals for transcription are conserved in each gene among the Filoviridae family, having the conserved consensus sequence of 3'CUNCNUNUAAUU-5' and 3'UAAUUCUUUUU-5' $(37,38)$. Intergenic regions have overlapping start and stop signals and separate the genes (37). Among filoviruses, the unique feature of EBOV is that the fourth gene encodes a minimum of two proteins; the second protein is expressed after the addition of adenosine at a stretch of seven adenosines into the mRNA $(40,41)$.

\section{STRUCTURE OF EBOV}

The EBOV members of Filoviridae family are approximately $80 \mathrm{~nm}$ in diameter and up to 14,000 $\mathrm{nm}$ in length (42). The structure of EBOV consists of an envelope, viral matrix, and nucleocapsid proteins (Figure 2). The envelope part contains transmembrane protein - glycoprotein (GP), the viral matrix contains the VP40 and VP24 proteins, and the nucleocapsid complex contains proteins such as nucleoprotein (NP), the RNA-dependent RNA-polymerase (L), the polymerase cofactor VP35 and the transcription activator VP30 (37).

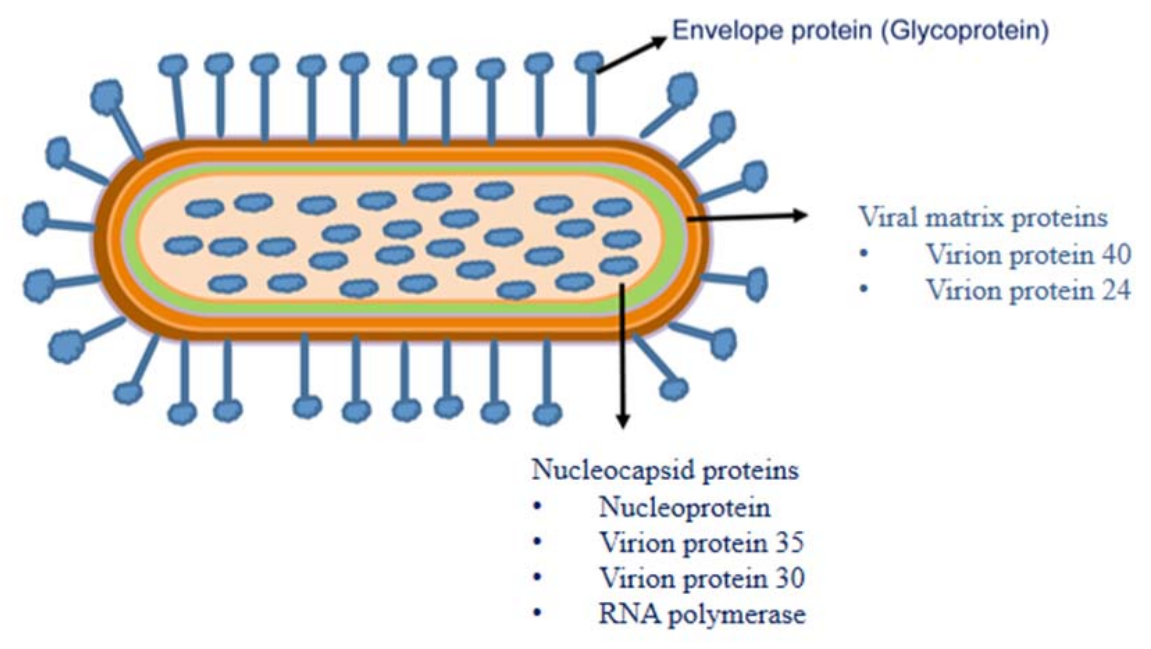

Figure 2: Structure of EBOV showing seven structural proteins of EBOV including Envelope protein (Glycoprotein), Viral matrix protein (Virion protein 40, Virion protein 24) and Nucleocapsid proteins (Nucleoprotein, Virion Protein 35, Virion Protein 30, RNA Polymerase)

\section{Envelope Protein}

\section{Glycoprotein (GP)}

Viral GP is 681 amino acids, $450 \mathrm{kDa}$ structural transmembrane protein. The GP contributes to the pathogenesis of Ebola virus by causing cytotoxicity in cells and damaging endothelial cells (43). GP has a trimeric crystal structure and consists of a highly glycosylated region known as the mucin domain, which induces cell cytotoxicity in infected host cells $(44,45)$. The GP forms spike-like structures on the viral surface and helps in attachment and entry of the virus $(46,47)$. The GP is expressed in large amounts in infected cells and also circulates in the blood, making it an attractive target for Ebola antigen screening procedures, as it can be screened from the blood of infected patients (48). 


\section{Viral Matrix Proteins}

\section{Virion Protein 40 (VP40)}

The $37 \mathrm{kDa}$ VP40 is a 326 amino acid, peripheral matrix protein. This protein is transported to the plasma membrane by exploiting the retrograde late endosomal pathway (49). It may occur in hexamer $(50,51)$ and octamer $(52,53)$ forms in infected cells, binding to the inner surface of the plasma membrane and helping to form new virus particles (54). Abundantly present in the cytoplasm of infected cells (55), VP40 supports in membrane association, capsid assembly, and budding of the virus. Due to its abundance in the infected host cells, it is a good candidate for developing antigen detection assays.

\section{Virion Protein 24 (VP24)}

VP24 is a matrix protein that is 251 amino acids long, with a molecular weight of $28 \mathrm{kDa}$ (56). It remains in inclusion bodies in infected cells, interacting with NP (57) for its localization, and helping in the packaging of the viral RNA genome. As well, VP24 has been reported to interfere with the interferon signaling pathway (58). VP24 is a minor matrix protein, and it is associated with lipid membranes (59). Therefore, the protein is not a suitable diagnostic target.

\section{Nucleocapsid Proteins}

\section{Nucleoprotein (NP)}

Nucleoprotein (NP) is 739 amino acid long (83.3 $\mathrm{kDa})$, sialylated, O-glycosylated structural protein (60). Along with RNA-dependent RNA polymerase and the viral RNA, NP forms a nucleoprotein complex (61), helping in the transcription and replication of RNA. The NP has ten linear B-cell epitopes, ten antigenic sites, and five surface accessible epitopes, predicted as a conserved region among EBOV species. Among these regions, GEQYQQLR has been reported to have immunogenic and antigenic properties, making NP a suitable target for antigen detection and treatment of EVD (62).

\section{Virion Protein 35 (VP35)}

VP35 consists of approximately 340 amino acids and its molecular weight is $37 \mathrm{kDa}$. Containing a Cterminal dsRNA binding domain and acting as a cofactor of RNA-dependent RNA polymerase (63), VP35 plays important roles in transcription, replication, and assembly of the virus. It also has been reported to mask viral RNA from host innate immune system (64).

\section{Virion Protein 30 (VP30)}

VP30 consists of approximately 288 amino acids and its molecular weight is $33 \mathrm{kDa}$. It is a part of the viral RNA transcription complex, facilitating mRNA transcription. VP30 contains a zinc finger between amino acids 68 and 95. These zinc finger amino acids are necessary for transcription (65). In inclusion bodies, VP30 becomes phosphorylated, and in the cytoplasm of infected cells, it takes a non-phosphorylated form. Phosphorylation of VP30 inhibits transcription of the Ebola virus gene (66).

\section{Viral Polymerase (L Protein)}

The L protein consists of 2,212 amino acids and its molecular weight is $253 \mathrm{kDa}$. It acts as an RNAdependent RNA polymerase and has three domains: the RNA binding element, a phosphodiester bond formation domain, and a purine ribonucleotide triphosphate-binding domain (67). This is among the most conserved proteins in the order Mononegavirales and helps in transcription as well as replication.

\section{Pathophysiology of Ebola Virus}

The Ebola virus enters the host cell through the endocytic pathway (68) (Figure 3). EBOV infects endothelial cells, hepatic liver cells, dendritic cells, monocytes, and macrophages. Initially, the attachment of the virus VP35 to dendritic cells leads to the absence of an adaptive immune response (69). Then, the replication of EBOV in monocytes and dendritic cells causes cell damage, which leads to the release of cytokines and nitric oxide that contribute to fever and the body's inflammatory response $(70,71)$. Lymphocytes are depleted during EBOV infection and do not allow the host body to mount an adaptive immune response. The structural proteins also play a role in disease pathogenesis. The VP40 protein helps in the transport of the virus to the plasma membrane of the host cell. The plasma membrane has lipid rafts, which are the sites of budding and virus assembly (72). The RNAdependent RNA polymerase helps form the 


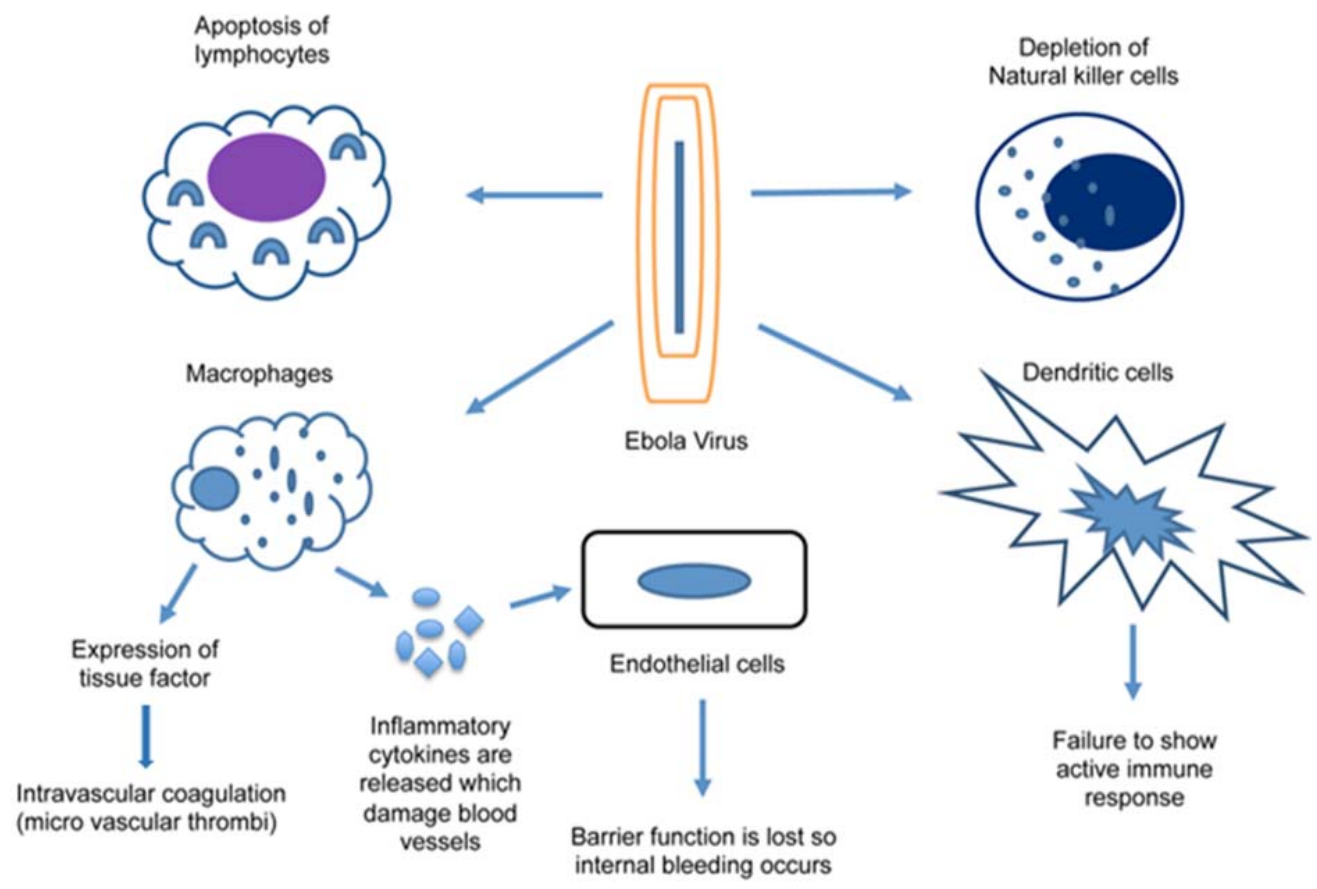

Figure 3: Pathophysiology of Ebola Infection: Immune cells affected by Ebola virus (lymphocytes, natural killer cells, dendritic cells and macrophages) upon entering into host cell.

transcription and replication complex, which transcribe viral genes and make multiple copies of the Ebola RNA genome, resulting in new virion assembly occurs after replication.

\section{Clinical Symptoms of Ebola Infection}

The first stage of clinical symptoms, known as early stage EVD (within 7 days), includes fever, diarrhea, appetite loss and vomiting. Late-stage EVD is generally characterized with internal and external bleeding (e.g. blood in the stools and gums), vomiting, chest pain, muscle pain, low white blood cell and platelets count (73). In severe cases, there is bleeding in the impaired liver and kidney functions with possibilities of multi-organ failure, ultimately resulting in death (74). During the outbreak it was observed that there were individuals who were in direct contact with EVD patients but never showed or developed any symptom. Therefore, it was concluded that EBOV infections can also be asymptomatic in some cases or only manifest at later stages of the disease. The reason behind this is that asymptomatic individuals have a strong inflammatory response characterized by higher concentrations of circulating cytokines and chemokines (75-77). Some symptoms of EVD, such as fever and vomiting, match symptoms of other tropical diseases such as cholera, but diarrhea remains for longer in EVD cases (7 days). Pregnant women, elderly and children (below 5 years of age) are the most vulnerable patient populations (73). This overlapping of symptoms makes a differential diagnosis of EVD very challenging. However, early (within 3 days post-infection) detection of EVD is critical, as the majority of patients succumb within 7-10 days of the appearance of clinical symptoms (9).

\section{CURRENT EBOLA DIAGNOSIS TECHNIQUES}

There are several methods currently available for the diagnosis of EBOV infection, but all have limitations, warranting more research in this area. Due to a relatively short incubation period of the infection and non-specific symptoms, a diagnosis 
should be fast and accurate. An ideal Ebola virus diagnostic method must satisfy the globally recommended features of an ideal diagnostic test, which follows the ASSURED principles. The acronym stands for A- affordable, S- specificity, Ssensitivity, U- User friendly, R- robust, Eequipment free and $\mathrm{D}$ - delivered to those in need (78). Currently, EVD can be detected by EBOV isolation from patient specimens, viral antigens (NP, GP, and VP40), and viral nucleic acid.

\section{Virus Isolation Methods}

Evaluating EBOV isolated from biopsied tissues or specimens collected from patients requires a highly sophisticated laboratory and technically trained staff. Ebola virus particles can be isolated from biopsied tissues (e.g. liver) under an electron microscope (79). Handling EBOV requires biosafety level 4 (BSL-4) experimental facilities, which are only available in a few countries (Table 2): Canada, Germany, Europe, the UK, and the USA (80). Even with all BSL-4 facilities and trained staff, screening analyses for virion are risky and time-consuming.

\section{Biosensors}

Researchers have developed an EBOV-detecting biosensor that consists of arrays of plasmonic nanoholes, each having a diameter of about 200 to $350 \mathrm{~nm}$. These arrays are metallic films and transmit light at particular wavelengths. When a solution containing live virus sample (from blood or serum) binds to the metallic surface of sensor, the effective refractive index changes and there is a shift in the resonance frequency of the transmitted light. The magnitude of the shift is detectable by the naked eye, indicating the presence and concentration of EBOV (81) at a detection limit of $10^{5} \mathrm{PFU} / \mathrm{ml}$. Although the biosensor method has a high signal throughput, it needs a proper alignment of light coupling with the bio detection volume and it has the drawback of non-specific binding, resulting in background shifting at lower analyte concentration (81). Therefore, these sensors are not suitable for point-of-care detection.

\section{Single Particle Interferometric Reflectance Imaging Sensor}

Recently, a new detection assay known as "Single Particle Interferometric Reflectance Imaging Sensor" was developed (82). In this method, the virus particles are captured by a silicon nanoparticle. A digital detection sensor enables counting of single virus particles. The imaging of the virus helps in identifying the virus based on its genome length. Discrimination by size of the imaged nanoparticles (i.e. virions) allows differentiation between modified viruses having different genome lengths and enables a reduction in the counting of nonspecifically bound particles to obtain the limit of detection of $5 \times 10^{3} \mathrm{PFU} / \mathrm{ml}$ in blood and serum, all within 2 hours (82).

\section{Nucleic Acid Detection Methods}

\section{RT-PCR}

EBOV can be detected by the presence of viral nucleic acid in biopsy or blood specimens. This is commonly accomplished by reverse transcriptionPCR (RT-PCR) assay, an extremely sensitive technique that unfortunately also yields falsenegative and false-positive results (83). Care must be exercised to transport the samples to prevent denaturation of viral RNA, and a high level of proficiency is required to perform RT-PCR. Sanchez et al. developed RT-PCR, which has showed increased sensitivity and lowered the assay time period as compared to conventional RT-PCR (84). In this RT-PCR, the cDNA synthesis and PCR amplification occurs in a single tube. This single tube RT-PCR has been used to detect ZEBOV and REBOV in tissues and body fluids obtained from Ebola infected patients. In this study, the authors did the molecular characterization of EBOV and detected EVD by RT-PCR assay (84). In a study by Gibb et al., one tube RT-PCR was developed for EVD diagnosis. Specifically, GP was detected in genetic material; one primer set was used with two differentially labeled fluorescent probes to identify ZEBOV and SEBOV (85). The study's authors used EBOGP-1D primer to calculate the limit of detection (LOD). LOD observed for ZEBOV RNA was 10 femtogram (fg) and for virus it was 8 PFU, whereas for SEBOV RNA it was $100 \mathrm{fg}$ and for virus it was 3 PFU. This assay was unique in its ability to simultaneously detect and distinguish between ZEBOV and SEBOV (85). Drosten and coworkers developed another one-step real-time reverse transcription (RT)-PCR (which consumes less time than traditional RT-PCR) (86). This assay uses the Platinum Taq polymerase enzyme mixture and products are analysed in real time on a light 
cycler instrument using Sybr green dye intercalation (86). These assays are validated analytically using in vitro-transcribed standard RNA as a positive control. The probability of detecting virus genome equivalents per $\mathrm{ml}$ of plasma was greater than $95 \%$, and the regression analysis ranged from 1,545 to 2,835 viral genome equivalents $/ \mathrm{ml}$ of serum i.e. 816 RNA copies per assay (86). Therefore, the assay is suitable for the detection and quantification of viral RNA in serum samples of EVD patients.

Another real-time RT-PCR-based method was developed to detect NP mRNA. This assay can detect as few as $10^{2}$ copies per microliter and has no cross-reactivity with other Filoviridae viruses (87). Using Taqman polymerase RT-PCR with enp T-F, enp T-R, enp-F and enp-R primers, the NP gene of the ZEBOV virus was amplified. This RT-PCR method, compared with standard ones, could detect

\section{Table 2: Biosafety Level 4 Laboratories}

\begin{tabular}{|c|c|}
\hline Name of Institute & Place \\
\hline National Microbiology Laboratory & Manitoba, Canada \\
\hline Wuhan Institute of Virology of the Chinese Academy of Sciences & Wuhan, China. \\
\hline European Union Mobile Laboratory Consortium & Paris, France \\
\hline National Institute for Medical Research & London, U.K \\
\hline National Institute of Health & Maryland, U.S.A \\
\hline National High Security Laboratory & Melbourne, Australia \\
\hline Wuhan Institute of Virology of the Chinese Academy of Sciences & Hubei, China \\
\hline Jean Merieux BSL-4 Laboratory & Rhone-Alpes, France \\
\hline Robert Koch Institute & Berlin, Germany \\
\hline Bernhard Nocht Institute for Tropical Medicine & Hamburg, Germany \\
\hline Philipps University of Marburg & Marburg, Germany \\
\hline National Center for Epidemiology & Budapest, Hungary \\
\hline High Security Animal Disease Laboratory & Bhopal, India \\
\hline National Institute for Infectious Disease & Tokyo, Japan \\
\hline National Institute for Communicable Disease & Johannesburg, South Africa \\
\hline Public Health Agency of Sweden & Solna, Sweden \\
\hline Institute of Medical Virology & Zurich, Switzerland \\
\hline Health Protection Agency’s Centre for Infections & Colindale, United Kingdom \\
\hline Centers for Disease Control and Prevention & Georgia, United States \\
\hline National Institute of Allergy and Infectious Diseases & Montana, United States \\
\hline Texas Biomedical Research Institute & Texas, United States \\
\hline Kenya Medical Research Institute & Nairobi, Kenya \\
\hline Uganda Virology Research Institute & Entebbe, Uganda \\
\hline WHO Collaborating Centre for arboviruses and viral hemorrhagic fevers & Dakar, Senegal \\
\hline International Centre for Medical Research in Franceville & Franceville, Gabon \\
\hline
\end{tabular}


up to a range of $10^{9}$ RNA copies per milliliter. This assay was assessed for rapid detection of ZEBOV as well as MARV. The quantification value of this viral RNA was $10^{4}$ to $10^{10}$ copy numbers per reaction for ZEBOV and $10^{3}$ to $10^{9}$ for MARV. Due to the reproducibility of this technique, it was deemed reliable. The viral genomic number calculated by this method was $4 \operatorname{logs}$ higher than a simple plaque titration method (88).

McKinney et al. developed an improved procedure for extracting RNA (by proteinase $\mathrm{K}$ digestion for 24 hours) from formalin-fixed, paraffin-embedded (FFPE) tissues followed by its detection by TaqMan RT-PCR (89). The tissues infected with BSL-4 biological agents had to be fixed in 10\% neutral-buffered formalin for 30 days before proceeding to molecular pathology studies. Besides this lengthy timeframe, formalin fixation is thought to cause irreversible modifications to the RNA. When the formalin-fixed tissues were used in RT-PCR assays, the detection limit for viral genome was reduced by $2 \operatorname{logs}_{10}$ times compared to fresh tissues (89).

One technique frequently used for the detection of EBOV RNA is the RealStar ${ }^{\circledR}$ Filovirus Screen RT-PCR Kit 1.0 from altona Diagnostics, targeting the L gene. During the 2014 Ebola outbreak, capillary blood samples were collected from finger pricks in order to detect EBOV using this kit. The total number of samples collected were 120 from 53 patients admitted to the Ebola Treatment Centre in Guéckédou, Guinea, and RealStar $^{\circledR}$ RT-PCR was used to examine these specimens. The results obtained from capillary blood samples were correlated with the samples taken by venipuncture. As compared to venous blood samples, capillary blood samples showed a sensitivity of $86.8 \%$. It was observed that if swabs of capillary blood samples are taken, then there were chances that RNA may get degraded, resulting in lower sensitivity (90).

\section{LAMP Assay}

Kurosaki et al. developed a reverse transcriptionloop-mediated isothermal amplification (RTLAMP) test to detect ZEBOV by targeting the viral genomic trailer region, since it is highly conserved among different strains of ZEBOV (91). In this trailer region, six sites were selected for binding of primers. The primers used were FIP, BIP, F3 and B3. In 26 min, RT-LAMP detected 20 copies of
ZEBOV RNA. The detection limit for real-time monitoring was $10^{-3} \mathrm{FFU}$ (focus forming unit) of the cell culture propagated virus. This assay is sensitive and specific and can detect $6.2 \times 10^{6}$ to $2.2 \times 10^{2}$ RNA copies per reaction. The limitation of this test is that it is unable to diagnose the disease with oral samples, such as saliva (91).

\section{DNA Fluorescence Method}

In 2005, $\mathrm{Li}$ et al. introduced a gene-guided approach to detect Ebola DNA, using DNA-based fluorescence nano-barcodes (92). These DNAbased, fluorescence-intensity-coded nano-barcodes, contains a built-in code and a probe for molecular recognition. This unique feature of nano-barcodes allows the detection of a pathogen's genetic material using fluorescence microscopy, flow cytometry, and dot blotting. The limit of detection was found to be $6.2 \times 10^{-16}$ moles within 30 seconds for Ebola DNA (92). This approach is rapid and sensitive, but not a good point-of-care diagnostic method, as it uses expensive equipment and infrastructure, and requires highly skilled personnel.

\section{Immunoassays: Detecting Viral Antigens}

During initial infection with EBOV, patients have high amounts of viral antigens circulating in their blood streams and excreted in urine, so antigen detection procedures have become a crucial focus for early diagnosis. Formenty et al. in a recent study demonstrated the suitability of oral fluid samples for the detection of EVD, as the RT-PCR results were positive for the oral fluid specimens obtained from EVD patients (93). Till now there is no study that has evaluated the use of oral fluid samples to diagnose EVD patients in Congo (93). Viral antigen can be detected in body fluids beginning at 3-6 days post infection. Over the course of infection, antigen titer may either decrease to negligible (i.e. for most survivors) or increase until death. Several EBOV antigen detection kits based on different antigens of the Ebola virus have been developed with varying specificity and sensitivity.

VP40 is abundantly present in the virusinfected cells and hence is a good target for diagnosis of EVD (94). In VP40-based sensitive sandwich ELISAs, the limit of detection of VP40 was $2 \mathrm{ng}(95)$. A recently developed ReEBOV rapid diagnostic was used to screen 28 patients at the point-of-care level and analyzed 45 patient blood samples in the laboratory. ReEBOV is a simple 
dipstick test and doesn't require electricity. This assay showed that the patients who were positive in real time RT-PCR assay (RealStar ${ }^{\circledR}$ Filovirus Screen RT-PCR kit 1.0; altona Diagnostics GmbH, Hamburg, Germany) were positive with this test as well. This ReEBOV diagnostic kit showed excellent specificity (92.2\%) and sensitivity (100\%) in both point-of-care and laboratory settings, when testing patients wtih high viral load. The assay showed $100 \%$ sensitivity and $92 \%$ specificity to detect EVD in people with a mild infection at the initial stage (96).

NP is considered a good diagnostic target, as it is also present in infected persons in early phase of infection. Niikura et al. developed monoclonal antibodies (mAbs) that detected as little as 33 $\mathrm{ng} /$ well of recombinant EBOV NP in an antigen capture ELISA (11). Ikegami et al. developed mAbs (Res2-6C8 and Res2-1D8) against REBOV NP. These antibodies showed high specificity and sensitivity for REBOV in macaques and did not react with the NP antigen of ZEBOV and SEBOV (97). The antigen capture ELISA developed using Res2-6C8 and Res2-1D8 mAbs can be a promising tool for the diagnosis of REBOV infection, especially in monkey quarantine and field studies. REBOV has not caused infection in humans, therefore this testing system can be useful for detection of REBOV infection in non-human primates (97).

The polyclonal antibodies (pAbs) and mAbs produced against soluble EBOV GP protein have revealed information about the diversity of this envelope protein and helped develop reagents that can be used in faster and accurate diagnostics. The $\mathrm{N}$-terminal, C-terminal, and mid-GP protein of SEBOV have been used to generate the pAbs. The C-terminus pAbs can detect GP protein of ZEBOV as well as SEBOV, whereas antibodies produced from central region or N-terminus of GP can detect only SEBOV (98). Three regions of GP protein were used to raise mAbs $15 \mathrm{H} 10,17 \mathrm{~A} 3$, and $6 \mathrm{D} 11$. The $15 \mathrm{H} 10$ recognizes human EBOV GPs of three species (SEBOV, ZEBOV, and TAFV) and nonhuman primates EBOV GPs of REBOV; 17A3 recognises human and non-human primate EBOV GPs of SEBOV and ZEBOV; and 6D11 recognizes EBOV GPs of SEBOV only in humans and nonhuman primates. These mAbs and pAbs have been used in ELISA, surface plasmon resonance, and quartz crystal microbalance immuno-sensor. In surface plasmon resonance, EBOV mAbs were immobilized on a sensor chip (CM5) by using standard amine coupling chemistry and EBOV GPs were injected to anti-EBOV $\mathrm{mAb}$ immobilized surface. The quartz crystal microbalance immunosensor comprises of gold electrode and antibody capture agent (Protein A, Protein G or Protein L). The steps in assembly of the sensor involved the cleaning of gold electrode with piranha (3:1 concentrated sulfuric acid; $30 \%$ hydrogen peroxide). The quartz crystal was placed in the flow cell, washed (50 $\mathrm{mM}$ phosphate buffer) and brought to resonant frequency of $5 \mathrm{MHz}$. Capture agent (concentration range of $2-5 \mu \mathrm{M}$ ) diluted in acetic acid (100 mM, pH 4.5) or in 50/50 acetic acid/phosphate buffer was introduced to the sensor until binding saturation was reached for the detection of GP protein (98). Lucht et al. generated GP-specific mAbs 3B11 and 1G12. 3B11 was specific to ZEBOV whereas $1 \mathrm{G} 12$ was specific to TAFV (48). These mAbs were used in a sandwich ELISA, in which mAb 3B11 was used as capture and $1 \mathrm{G} 12$ as the detection antibody at an optimized concentration of $5 \mu \mathrm{g} / \mathrm{ml}$ and $20 \mu \mathrm{g} / \mathrm{ml}$, respectively. The limit of detection observed for GP viral antigen was $10^{3} \mathrm{PFU} / \mathrm{ml}$ in serum (48).

MIT Researchers have developed a "Lab on a Chip" that can detect EVD in 10 minutes (99). This silver nanoparticle-coated paper-based strip is a type of lateral flow immunochromatographic assay. The patient's blood serum flows along the paper strip where immobilized anti-GP antibodies bind to the GP viral protein. A positive test result (the formation of Ebola antigen-Ab complexes) is visualized as a red band on the strip. The limit of detection for ZEBOV GP antigen for this "Lab on a Chip" procedure is $150 \mathrm{ng} / \mathrm{ml}$. The advantages of this testing procedure are that it is extremely rapid detection method $(10 \mathrm{~min})$ with no requirement for electricity. It can detect other viruses in the blood sample simultaneously. The limitation of this multiplex approach is that can show false positive, non-specific binding, and crossover results (99) Hence, it is not a reliable diagnostic technique.

Lucht et al. has also developed an immunofiltration-based antigen detection assay that can detect VP40 protein of EBOV in urine in about 30 minutes. In this assay one $\mathrm{mAb}$ binds to the matrix of column to immobilize EBOV VP40 and the second biotin labeled $\mathrm{mAb}$ used for detection of the bound viral antigen. In spiked urine samples, the 
VP40 antigen from ZEBOV was detected at a limit of $1.25 \times 10^{4} \mathrm{PFU} / \mathrm{ml}$. This new immunofiltration assay could provide a novel platform for future studies of EVD outbreaks. Although less sensitive than RT-PCR analysis, the assay showed comparable sensitivity to that of the widely used antigen-detection ELISA (100).

\section{Immunochromatographic Strip}

An immunochromatographic "Nanozyme" strip, embedded with ferric oxide magnetic nanoparticles, can detect EBOV GP with as low as $1 \mathrm{ng} / \mathrm{ml}$ of antigen (101). The diagnosis of EBOV infection can be made in just $30 \mathrm{~min}$ using this strip. This Nanozyme-strip has intrinsic peroxidase-like activity that catalyzes the peroxidase substrate and produces a color reaction. In this study, metal nanoparticle were used as a nanozyme probe. After labeling with anti-EBOV antibody, this probe was able to identify, separate, and visualize EBOV on the nanozyme strip. Low cost and reusable are two advantages that makes this strip a suitable candidate for biomedical detection. Unfortunately, this strip has not been tested for ZEBOV, the species that is the major cause of outbreaks and leads to a significant number of deaths. This strip is less sensitive than RT-PCR; that means it cannot diagnose EVD immediately after the appearance of symptoms and $15 \%$ false positive rate also limits its application.

\section{Microfluidic Chip}

In 2014, Miethe et.al. Devised a rapid detection test for VP40 antigen. They performed the assay in a microfluidic chip for immune filtration analysis (102). The device has anti VP40-polyHRP40 stored as dry pellet in the reservoir. The sample injection port goes to a series of four immunofiltration frits. The liquid enters from the bottom and flows through the frits. This liquid leaves through the top of frits and is brought back through microfluidic to the bottom of the chip so as to enter the next frit. This arrangement allows the identification of VP40 with a positive and a negative control. The fiber optic setup was used for the photometric read-out in transmission mode. The polyethylene filter exhibits a pronounced light scattering and the optical densities were determined following Beer Lambert law. All these test components detect the antigen. The detection limit for recombinant VP40 was 8 $\mathrm{ng} / \mathrm{ml}$. In serum and blood samples containing viral culture material the limit of detection was found to be $2.2 \times 10^{2} \mathrm{PFU} / \mathrm{ml}$. The time taken by the microfluidic chip to detect the antigen was 15 minutes. The drawback is that it needs skilled personnel to read the results.

\section{MARSA (Monoclonal Affinity Reagent Sandwich Assay)}

Monoclonal affinity reagent sandwich assay (MARSA) uses one recombinant antibody clone as both the capture as well as the tracer to detect the EBOV NP. The Ab consists of a single domain targeting the conserved domains of NP protein. The polyvalent nature of NP enables the formation of a sensitive sandwich immunoassay (103).

Changula et al. developed mAbs to the ZEBOV NP and identified NP's conserved and antigenic regions (104). These mAbs were then divided into seven groups according to the specificity and cross-reactivity profiles to other species in the EBOV. The binding sites of the mAbs were mapped to seven antigenic regions in the $\mathrm{C}$ terminal half of the NP including two highly conserved regions among all species of EBOV by using synthetic peptides corresponding to the EBOV NP sequence. These techniques provide information about antigenic sites that can help in forming other monoclonal affinity reagent driven antigen sandwich assays for the Ebolavirus genus and in the development of viral antigen detection assays, such as an immunochromatography-based rapid diagnosis.

\section{Comparison Diagnosis of EVD by RT-PCR and Antigen Capture ELISA Diagnostics}

The EVD outbreak occurred in the Gulu district of northern Uganda, with secondary transmission to other districts. National Institute for Virology in Johannesburg, South Africa, did the preliminary diagnosis of SEBOV and a temporary diagnostic laboratory was established in the Gulu district. The laboratory used a combination of antigen capture and reverse transcription-PCR (RT-PCR) to detect SEBOV infection in suspected patients. These assays (RT-PCR and antigen-capture) proved very efficient for diagnosing EVD in patient serum, plasma, and whole blood. In total 49 serum samples that showed positive results by antigen capture ELISA, only 30 samples tested positive by RTPCR. All positive samples tested by RT-PCR also showed positive results tested by antigen-capture 
ELISA. Therefore, this study concluded that RTPCR is a useful assay, but should always be used with a reliable test, such as antigen-capture ELISA (9).

\section{Immunoassays: Detecting Viral Antibodies}

The presence of serum antibodies against a pathogen is considered as the primary assay used for diagnosis. However, in EVD, specific antibodies are generally only detectable in the late phase of infection or sometimes may be undetectable. For example, IgG and $\operatorname{IgM}$ antibodies against EBOV are observed in individuals after 8-10 days postinfection or in individuals who have recovered from the virus infection (10). IgM antibodies are identified in the first week after onset of symptoms, reaching peak levels in the third week (18 days) after symptom onset and disappearing after six weeks of infection. IgM screening assays cannot detect $\operatorname{IgM}$ antibodies after 60 days of virus infection. Furthermore, IgM antibodies are found in only half of the patients at the time of their death (10).

IgG antibodies appear between 8-10 days after the appearance of IgM antibody in Ebola infection and can be seen for up to ten years (105). In similar cases, however, IgG antibodies were not detected regardless of infection phase. The sample used for $\mathrm{Ab}$ detection plays an important role. Formenty et al. collected samples from patients between 10-24 days post-EBOV infection and reported positive results for anti-Ebola IgG antibodies from serum samples, but negative for oral samples (93). In another study, recombinantexpressed NP and GP proteins positively reacted in ELISA with $\operatorname{IgG}$ antibodies present in human convalescent sera only (106). Ikegami and coworkers used an immunofluorescence assay (IFA) to detect serum antibodies with recombinant NP (107). The results of their studies showed that the assay was more sensitive for the detection of IgG antibodies in serum samples of monkeys infected with REBOV than ZEBOV. This IFA method could be useful in seroepidemiological studies of REBOV infected monkeys, but not for human diagnostics. Collectively, these studies demonstrate that an IgG-based assay is not a good option for early stage diagnosis of EVD.

On a positive note, a baculovirus-expressed $\mathrm{NP}$ antigen used to detect $\mathrm{IgG}$ antibodies in an ELISA assay showed positive results for IgG detection in sera of patients, with $93 \%$ sensitivity (108). The authors of this study identified that the C-terminal region of NP was highly antigenic, which suggests that these antigenic regions could be used for detection of EVD.

In another study, histidine-tagged recombinant GP of five different EBOV species and one MARV species were used as antigens for the detection of filovirus species-specific antibodies (109). The authors developed an IgG antibody detection ELISA by collecting antisera from immunized mice, EBOV infected humans, and nonhuman primates. The anti-EBOV-GP mAb ZGP42/3.7 and anti-MARV-GP mAb AGP127-8 were used to determine the sensitivity of ELISA. The researchers observed that ZGP42/3.7 reacted with the recombinant GP of all the EBOV species, whereas AGP127-8 mAb reacted only with recombinant GP of MARV. The limit of detection for specific antibodies ( $\mathrm{IgG}$ ) observed using GP antigen in ELISA was approximately $0.1 \mu \mathrm{g} / \mathrm{ml}$. This study helped in distinguishing the serotypes of filovirus species, as GP is species-specific protein due to the greater genetic variability with this protein (109).

In Yambio Payam, Sudan, a study of 36 patients with probable EVD yielded 13 EVDconfirmed patients, with 8 having both $\operatorname{IgG}$ and IgM against Ebola virus and 4 having IgM antibodies only (110). These 12 patients had complete disease remission. Another patient whose blood sample was collected after two days of illness that was confirmed by RT-PCR did not show antibodies against the virus. The EVD patient died after 10 days of illness. The authors observed that blood samples collected after two days of illness showed a positive result for EBOV using RT-PCR, but not for $\operatorname{IgM} / \operatorname{IgG}$ antibody ELISA. The study concluded that antibodies were not present in the initial phase, whereas they were present after patient recovery. Once again, this study shows that the diagnosis of EVD with antibody-based ELISA is not a good option for early screening (110).

\section{Synthetic Gene Network}

Pardee et al. developed a paper-based synthetic gene network to detect and screen for EBOV using engineered gene circuits and visual transduction (colorimetric outputs of circuits present in gene network for detection by eye (111). The synthetic gene network is freeze-dried onto paper by freeze- 
drying. These synthetic gene circuits are composed of a sensor element and a transducer that regulates a measureable output. This engineered logic has sequence-specific sensing of nucleic acids and small-molecule recognition. The glucose sensors as well as strain-specific sensors help in in-vitro diagnosis of virus. This approach can detect antiEbola antibodies in a cost-effective, rapid, and sensitive manner. The limitation of this approach is that it cannot be used for primary disease diagnosis. Earlier cell-based synthetic networks have also used for detection of EVD. However, their application is restricted to the laboratory due to the biosafety concerns (111).

\section{LIMITATIONS OF CURRENT DIAGNOSTICS}

We have discussed many different Ebola diagnostic tests available, based on various technologies and viral components. All of these screening procedures have limitations, some of which were discussed (Table 3).

Virus isolation and identification by electron microscope is $100 \%$ accurate, but requires an expensive, well-equipped BSL-4 laboratory and presents a high risk to handlers of patient specimens containing live virus. Despite being a useful tool for diagnosis of EBOV, RT-PCR based methods are time-consuming (greater than 48 hour turn-around) and can yield either false positive or negative results (9). Additionally, PCR-based techniques might not detect newly emerged or vastly divergent strains of an infectious virus. The example of this is the current description of a new strain of Ebola that was not recognized in initial PCR-based diagnostics (17).

Most antigen-based ELISAs detect Ebola viral antigens such as GP, NP, or VP40 with such low sensitivity and specificity that the diagnostic test results need to be correlated with other epidemiological and clinical parameters of Ebola infection before concluding Ebola infection in tested patients. For tissue samples, the sensitivity and specificity of antigen-based ELISA were promising. Sensitivity tested in animals infected with the EBOV showed $98 \%$ in the liver and 93\% in the spleen (112). However, it takes five hours to show the results. Developed by Corgenix, USA and now available on the market, ReEbOV antigen rapid test kits do not require a power source and are easy to perform, making this an ideal point-of-care test. Although less accurate, they can detect $92 \%$ of patients infected with EVD.

Immunological assays can detect Ebola antigen-specific IgM and IgG antibodies, but these methods are not useful at the time of initial infection, since these antibodies surface 10-20 days post-infection and remain in the patient's bloodstream for up to 2 years after being infected, due to the development of a specific immune response (10).

\section{NEW TOOLS FOR EBOLA DIAGNOSIS}

\section{Single Domain Antibodies}

Single domain antibodies (sdAbs) are the small (14 $\mathrm{kDa}$ ) fragments, which are thermo stable in nature and have a good shelf life (113). They have the capability to refold and bind to antigen once denatured and can be produced with different specificities. These features make sdAbs ideal for Ebola diagnostic development. In contrast, $\mathrm{mAb}$ production is time-consuming, and under extreme environmental/storage conditions (e.g. temperatures $>65 \mathrm{C}$ ), the $\mathrm{Ab}$ heavy and light chains unfold and aggregate irreversibly (113).

Shonda et al. developed a single molecule array (Simoa) in which sdAbs are chemically attached to a paramagnetic surface for the detection of ricin (114), a potent ribosome-inactivating protein that can inactivate 1500 ribosomes/min and cause cellular necrosis, followed by death of the person exposed to this toxin. Since there is no treatment for ricin poisoning, a very sensitive detection assay is required. The Simoa method detected $1 \mathrm{pg} / \mathrm{ml}$ of ricin in a buffer, urine, and serum samples. This approach showed its applicability for detecting ricin in environmental, food, and clinical specimens (114). sdAbs have been used to detect the presence of amyloid bodies in the brains of Alzheimer's patients (113). These FITC-labelled sdAbs bind to intraneuronal amyloid body peptides and stain extracellular plaques. These results show that sdAbs are very useful in the diagnosis of diseases and should be considered for developing Ebola-specific assays (113).

sdAbs have various advantages over traditional technologies such as immunotherapy (115). They have high binding affinity and specificity to the target of interest. These can easily be tagged with fluorescent proteins to produce color for detection of a particular moiety (115). The shelf 
Table 3- Advantages and Disadvantages of Diagnostics Available

\begin{tabular}{|c|c|c|c|}
\hline Diagnostic Tests & Target & Advantages & Limitation \\
\hline $\begin{array}{l}\text { Polymerase Chain } \\
\text { Reaction (PCR) }\end{array}$ & $\begin{array}{l}\text { Nucleic acid of } \\
\text { virus }\end{array}$ & $\begin{array}{l}\text { - Rapid and sensitive } \\
\text { - Quantification of RNA molecule }\left(10^{4}\right. \\
\text { to } 10^{10} \text { per reaction) }\end{array}$ & $\begin{array}{l}\text { Require special equipment (Huang } \\
\text { et al.2012) }\end{array}$ \\
\hline $\begin{array}{l}\text { DNA-based } \\
\text { fluorescence } \\
\text { nanobarcodes } \\
\text { methodology } \\
\end{array}$ & $\begin{array}{l}\text { Nucleic acid of } \\
\text { virus }\end{array}$ & $\begin{array}{l}\text { - Multiplexed approach for detection. } \\
\text { - Detection limit is } 620 \text { attomole. }\end{array}$ & Require skilled personnel. \\
\hline $\begin{array}{l}\text { ELISA (antigen } \\
\text { detection) }\end{array}$ & Viral antigen & $\begin{array}{l}\text { - Rapid and sensitive. } \\
\text { - } 30 \mathrm{ng} / \text { well of recombinant NP antigen } \\
\text { could be detected (Niikura, et al.2001) }\end{array}$ & Sometimes provide false results. \\
\hline Immunohistochemistry & Viral antigen & - It's a qualitative imaging method. & Time required. \\
\hline Fluorescence assay & Viral antigen & $\begin{array}{l}\text { - Rapid technique. } \\
\text { - Qualitative analysis. }\end{array}$ & $\begin{array}{l}\text { Interpretation of results requires } \\
\text { skilled personnel. }\end{array}$ \\
\hline $\begin{array}{l}\text { ELISA (antibody } \\
\text { based) }\end{array}$ & $\begin{array}{l}\text { Virus specific } \\
\text { antibodies }\end{array}$ & $\begin{array}{l}\text { - Sensitive and specific technique. } \\
\text { - Can detect upto } 20 \text { ng of EBOV Zaire } \\
\text { GP protein. }\end{array}$ & $\begin{array}{l}\text { Time required. } \\
\text { Primary disease diagnosis is not } \\
\text { possible. }\end{array}$ \\
\hline $\begin{array}{l}\text { Indirect } \\
\text { Immunofluorescence } \\
\text { assay }\end{array}$ & $\begin{array}{l}\text { Virus specific } \\
\text { antibodies. }\end{array}$ & $\begin{array}{l}\text { - Easy to perform } \\
\text { - Qualitative imaging method }\end{array}$ & $\begin{array}{l}\text { Non-specific technique. } \\
\text { Interpretation of results is difficult }\end{array}$ \\
\hline Immuno-blot assay & $\begin{array}{l}\text { Virus specific } \\
\text { antibodies }\end{array}$ & $\begin{array}{l}\text { - Specific technique. } \\
\text { - Easy to perform }\end{array}$ & $\begin{array}{l}\text { Interpretation of results is difficult } \\
\text { sometimes. }\end{array}$ \\
\hline Biosensors & Virus detection & $\begin{array}{l}\text { - Based on antibody based specific } \\
\text { detection. } \\
\text { - Rapid and sensitive } \\
\text { - Limit of detection is } 0.005 \mathrm{PFU} / \mathrm{ml}\end{array}$ & $\begin{array}{l}\text { Based on antibody detection results, } \\
\text { so cannot be used for primary disease } \\
\text { diagnosis. As antibodies are generated } \\
\text { in patient body on } 7^{\text {th }} \text { day and remains } \\
\text { up to } 3 \text { months. }\end{array}$ \\
\hline Electron Microscopy & $\begin{array}{l}\text { Viral particles } \\
\text { detection }\end{array}$ & $\begin{array}{l}\text { - Immunostaining method used. } \\
\text { Morphology can be seen. } \\
\text { - Qualitative analysis. }\end{array}$ & $\begin{array}{l}\text { Insensitive technique. } \\
\text { Needs special equipment. }\end{array}$ \\
\hline $\begin{array}{l}\text { Immuno- } \\
\text { chromatographic strip }\end{array}$ & $\begin{array}{l}\text { Glycoprotein } \\
\text { antigen }\end{array}$ & $\begin{array}{l}\text { - Sensitive method. } \\
\text { - Limit of detection } 1 \mathrm{ng} / \mathrm{ml} \text { of GP } \\
\text { antigen. }\end{array}$ & It is not tested for ZEBOV. \\
\hline $\begin{array}{l}\text { Next generation } \\
\text { sequencing }\end{array}$ & $\begin{array}{l}\text { Viral genetic } \\
\text { material }\end{array}$ & $\begin{array}{l}\text { - Sequence large amount of genetic } \\
\text { material. } \\
\text { - Remarkable depth of covering } \\
\text { sequence of genetic material }\end{array}$ & $\begin{array}{l}\text { Do not identify sequence of interest } \\
\text { and sequence all the host genetic } \\
\text { material present. }\end{array}$ \\
\hline LAMP assay & Virus & $\begin{array}{l}\text { - Limit of detection was } \\
10^{-3} \text { FFU. }\end{array}$ & Unable to detect virus in oral samples. \\
\hline $\begin{array}{l}\text { Immunofluorescence } \\
\text { assay }\end{array}$ & NP antigen & $\begin{array}{l}\text { - Sensitive for the serum samples } \\
\text { infected with REBOV and ZEBOV. }\end{array}$ & $\begin{array}{l}\text { Detect antibodies to EBOV so cannot } \\
\text { be used for initial screening of EVD }\end{array}$ \\
\hline
\end{tabular}

life of sdAbs maintains their integrity of antigen binding even after storage for a few months at $4^{\circ} \mathrm{C}$ and for several months at $-20^{\circ} \mathrm{C}$. sdAbs can be produced economically in microbial expression systems within a short period of time and they are less immunogenic in nature and have an efficient refolding capacity. All these features make sdAbs good candidates for future Ebola diagnostic assays (115).

\section{IgY-based ELISA}

Another immune-diagnostic system, which is simple, reliable, sensitive, rapid, and robust and has the potential to detect disease at an earlier stage, 
relies on polyclonal, chicken-produced IgY. In chickens, the IgG from serum is transferred to eggs in the form IgY. When hens are immunized, high titers can be maintained up to 720 days (116). IgY antibodies can be obtained noninvasively from eggs in large quantities within a short period of time. Studies show that a laying hen can produce antibodies 18 times higher than the production of antibodies in other lab animals (e.g. rabbit and mouse) (117). Specifically, a laying hen can produce $2 \mathrm{~g}$ of antibody every month (118). These antibodies are stable under different conditions of $\mathrm{pH}$, pressure, acidity, and alkalinity and also in the presence of proteolytic enzymes, trypsin and chymotrypsin (119). Additionally, IgY does not cross react with mammalian immune components (WBC, lymphocytes, natural killer cells) (117).

IgY is already being used for diagnosis of some infectious diseases, such as Dengue, hepatitis, and SARS, binding viral antigen with high affinity and no cross-reactivity with other viral proteins (120). IgY antibodies, obtained from NS1 protein(of Dengue type 2 virus)-immunized chickens, were used with a potentiometric immunosensor containing a gold electrode immobilized with antiNS1 IgY antibodies. This IgY-immunosensor provided an efficient measurement of NS1 protein (121). IgY also proved to be useful in detecting hepatitis A virus (122). An immuno-enzymatic assay using IgY conjugated with horseradish peroxidase (HRP) as detector antibody was used to detect anti-hepatitis antibody levels. This test showed a sensitivity of $95 \%$ and specificity of $98.8 \%$, which shows that competitive immunoassay using IgY can substitute for other tests like ELISA that use mammalian antibodies (122).

An immunomagnetic bead ELISA has been developed, where IgY Abs coated with magnetic beads are used as capture antibodies to detect clonorchiasis caused by the liver fluke, Clonorchis sinensis (123). HRP-IgG is used as a detector antibody. The results of this IgY immunoassay show a sensitivity of $93.3 \%$ when there is a heavy parasite load and $75 \%$ when there is light infection. In this assay, cross-reactivity is observed with other parasitic worms: $6.7 \%$ with Schistosoma japonicum and $10 \%$ with the nematode causing paragonimiasis. The findings suggest that IgYIMB-ELISA is relatively sensitive and specific for the detection of clonorchiasis (123). A sandwich ELISA has been developed for the detection of excretory-secretory antigens of Trichinella spiralis, which causes trichinellosis (124). IgY is used as capture antibody and IgM mAb against excretorysecretory antigen is used as detector antibody and HRP-conjugated sheep anti-mouse IgM is used as secondary antibody; the limit of detection for this assay is $1 \mathrm{ng} / \mathrm{ml}$. The sandwich ELISA was sensitive and proved to be successful in early detection of disease (124).

Sandwich ELISA using IgY has also been used to detect prostate-specific antigen, which is a marker for prostate cancer, with a detection limit of $50 \mathrm{pg} / \mathrm{ml}$, and the reactivity profile of $\operatorname{IgY}$ was comparable to that of mouse monoclonal IgG antibodies. This study showed that IgY can be used in the diagnosis of prostate cancer and can replace mammalian antibodies (IgG) that are difficult to produce and costly (125).

\section{Bispecific Antibodies}

Bispecific antibodies (BsAb) are a second generation $\mathrm{mAb}$, characterized by dual functions: $\mathrm{a}$ $\mathrm{BsAb}$ is a single molecule with two different binding sites specific for two different moieties (126). One paratope is specific for the diseaserelated antigen or protein, whereas the other paratope is specific for the assay detection enzyme. In ELISA, the use of BsAb provides accurate and reproducible results, with a reduced probability of false positive results (127). Since BsAb has an intrinsic binding site for the detection enzyme, it avoids the step of chemical conjugation, which can be responsible for the loss of activity of the antibody or the protein, aggregation, and formation of unwanted complexes (128). Therefore, the use of $\mathrm{BsAb}$ is advantageous as they are inexpensive and can augment the level of ELISA detection by their specificity and sensitivity. With BsAbs, viral samples can be analyzed faster and less expensively than traditional ELISA protocols, as there is only one step of adding reagents rather than adding several reagents (129-131). Bispecific antibodies have better binding affinity to their target antigen compared to $\mathrm{mAbs}$, and can be better candidates for molecular targeting and imaging, as they have high specificity (132).

We know that it is imperative to screen for EVD accurately at early stages of infection, as with time, it becomes severe and incurable, leading to higher mortality rates. Therefore, BsAbs can play a significant role in diagnostic assay development to 
help to easily and quickly identify the disease at an early stage.

\section{CONCLUSION}

EVD is endemic in tropical regions, with occasional deadly outbreaks worldwide. Due to the increasing incidence, lack of treatment, and high mortality of Ebola virus infection, there is an urgent need to develop rapid, simple, accurate, inexpensive, and effective diagnosis methods. The disease has to be tracked and monitored at an early stage so that it could be prevented from spreading. There are many diagnostic tests available such as RT-PCR, antigenbased test kits, and ELISA kits, but none of them meet all relevant criteria to be an ideal point-of-care diagnostic test. Therefore, diagnostic methods based on emerging technologies, such as a sandwich assay based on mAb, BsAb and/or IgY could be developed to detect antigen levels seen in patient body fluid samples for screening applications in hospital settings. In addition to ELISA assays, other easily administered tests such, as immunoswabs, Nanochip- or other immunohistochemistry-based tests should be developed to detect EVD in the field. Amidst the developments in the realm of rapid diagnostics, it is important to highlight a breakthrough research led by Dr. Kobinger at NML, Winnipeg in treating Ebola infection. The study showed complete remission of Ebola in non-human primates when treated with a unique antibody cocktail formulation (ZMapp) (133). The efficacy of ZMapp has been promising and exceeds similar experimental endeavors. Further research and clinical trials would be necessary to validate the use in case of another outbreak. Currently Ebola therapeutic options are focused on palliative care and isolation procedures for suspected EVD patients (134). The development of ZMapp has been a crucial step in treating infected patients in the near future.

\section{ABBREVIATIONS}

BEBOV: Bundibugyo Ebola virus, bsAbs: Bispecific monoclonal antibodies, EBOV: Ebola Virus, EHF: Ebola Haemmorhagic Fever, EVD: Ebola Virus Disease, FFU: Focus forming unit, GP: Glycoprotein, LLOV: Lloviu virus, mAbs: Monoclonal Antibodies, MARV: Marburg virus, NP: Nucleoprotein, PFU- Plaque forming unit,
RAVV: Ravn virus, REBOV: Reston Ebola virus, RT-LAMP: Reverse Transcription Loop Mediated Isothermal Amplification, sdAbs: Single domain antibodies, SEBOV: Sudan Ebola virus, TAFV: Tai forest Ebola virus, TCID: Tissue culture Infective dose, VP40: Virion Protein 40, ZEBOV: Zaire Ebola virus.

\section{AUTHORS’ CONTRIBUTIONS}

BS wrote the paper; AG reviewed and modified the paper; HS was responsible for the design of the paper, obtaining the funding, and edited the manuscript. All authors read and approved the final manuscript.

\section{ACKNOWLEDGMENTS}

We would like to thank Dr. Ravindra B Malabadi and Ms. Lindsey (Yeon) Kyoung Suh for editing and proof reading the manuscript.

\section{FUNDING}

This work is supported by Mitacs Globalink Fellowship Program (Award \#IT05329).

\section{REFERENCES}

1. Negredo A, Palacios G, Vazquez-Moron S, Gonzalez F, Dopazo H, Molero F, et al. Discovery of an ebolavirus-like filovirus in europe. PLoS Pathog. 2011; 7(10):e1002304. doi:10.1371/journal.ppat.1002304.

2. Kuhn JH, Bao Y, Bavari S, Becker S, Bradfute S, Brauburger K, et al. Virus nomenclature below the species level: a standardized nomenclature for filovirus strains and variants rescued from cDNA. Arch Virol. 2014; 159(5):1229-37. doi: 10.1007/s00705-013-1877-2.

3. Barrette RW, Metwally SA, Rowland JM, Xu L, Zaki SR, Nichol ST, et al. Discovery of swine as a host for the Reston ebolavirus. Science (New York, NY). 2009; 325(5937):204-6. doi: 10.1126/science.1172705.

4. Tracey C. Young M. Comparison of Two Ebola Hemorrhagic Fever Outbreaks: Uganda 2000-01 and Republic of the Congo 2001-02. J Glob Health. 2013; 3(2).

5. McCormick JB, Bauer SP, Elliott LH, Webb PA, Johnson KM. Biologic differences between strains of Ebola virus from Zaire and Sudan. J Infect Dis. 1983; 147(2):264-7. doi: 10.1093/infdis/147.2.264. 
6. Messaoudi I, Amarasinghe GK, Basler CF. Filovirus pathogenesis and immune evasion: insights from Ebola virus and Marburg virus. Nat Rev Microbiol. 2015; 13(11):663-76. doi: 10.1038/nrmicro3524.

7. Madlen davies. Ebola 'treatment' made from the blood of survivors is being traded on a new black market emerging amid the outbreak. [press release]. Daily Mail2014.

8. Bah EI, Lamah MC, Fletcher T, Jacob ST, BrettMajor DM, Sall AA, et al. Clinical presentation of patients with Ebola virus disease in Conakry, Guinea. N Engl J Med 2015; 372(1):40-7. doi: 10.1056/NEJMoa1411249.

9. Towner JS, Rollin PE, Bausch DG, Sanchez A, Crary SM, Vincent M, et al. Rapid diagnosis of Ebola hemorrhagic fever by reverse transcriptionPCR in an outbreak setting and assessment of patient viral load as a predictor of outcome. J Virol 2004; 78(8):4330-41. doi: 10.1128/JVI.78.8.43304341.2004.

10. Ksiazek TG, Rollin PE, Williams AJ, Bressler DS, Martin ML, Swanepoel R, et al. Clinical virology of Ebola hemorrhagic fever (EHF): virus, virus antigen, and $\mathrm{IgG}$ and $\mathrm{IgM}$ antibody findings among EHF patients in Kikwit, Democratic Republic of the Congo, 1995. J Infect Dis 1999; 179 Suppl 1:S17787. doi: $10.1086 / 514321$.

11. Niikura M, Ikegami T, Saijo M, Kurane I, Miranda ME, Morikawa S. Detection of Ebola viral antigen by enzyme-linked immunosorbent assay using a novel monoclonal antibody to nucleoprotein. J Clin Microbiol 2001; 39(9):3267-71. doi: 10.1128/JCM.39.9.3267-3271.2001.

12. Rougeron V, Feldmann H, Grard G, Becker S, Leroy EM. Ebola and Marburg haemorrhagic fever. J clin virol : the official publication of the Pan American Society for Clinical Virology. 2015; 64:111-9. doi: 10.1016/j.jcv.2015.01.014.

13. World Health Organization. Ebola haemorrhagic fever in Zaire, 1976. Report of an International Commission. Bull World Health Organ. 1978; 56 (2):271-293.

14. World Health Organization. Ebola haemmorhagic fever in Sudan, 1976.; Report of a WHO/International Study Team. Bull World Health Organ.1978; 56(2):247-270.

15. Bwaka MA, Bonnet MJ, Calain P, Colebunders R, De Roo A, Guimard Y, et al. Ebola hemorrhagic fever in Kikwit, Democratic Republic of the Congo: clinical observations in 103 patients. J Infect Dis 1999; 179 Suppl 1:S1-7. doi: 10.1086/514308.

16. World Health Organization report. Ebola outbreak contained in Uganda. 2008 [Available from: http://www.who.int/features/2008/ebola_outbreak/en Accessed on 26 February 2016.

17. Towner JS, Sealy TK, Khristova ML, Albarino CG,
Conlan S, Reeder SA, et al. Newly discovered ebola virus associated with hemorrhagic fever outbreak in Uganda. PLoS Pathog. 2008; 4(11):e1000212. doi.org/10.1371/journal.ppat.1000212.

18. Centers for Disease Control and Prevention. Outbreaks Chronology: Ebola Virus Disease 2016 [Available from: http://www.cdc.gov/vhf/ebola/outbreaks/history/chr onology.html Accessed on 1-03-2016

19. World Health Organization Situation Reports. Ebola data and statistics.2016 [Available from: http://apps.who.int/gho/data/view.ebola-sitrep.ebolasummary-latest?lang=en Accessed on 1-03-2016.

20. Drazen JM, Campion EW, Rubin EJ, Morrissey S, Baden LR. Ebola in West Africa at One Year - From Ignorance to Fear to Roadblocks. N Engl J Med 2015; 372(6):563-4. doi: 10.1056/NEJMe1415398.

21. World Health Organization Ebola Response Team. Ebola virus disease in West Africa--the first 9 months of the epidemic and forward projections. $\mathrm{N}$ Engl J Med 2014; 371(16):1481-95. doi: 10.1056/NEJMoa1411100.

22. Centers for Disease Control and Prevention. 2014 Ebola outbreak in West Africa - Case Counts [Available from: http://www.cdc.gov/vhf/ebola/outbreaks/2014-westafrica/case-counts.html Accessed on 5-03-2016.

23. World Health Organisation. Ebola Situation Reports 2016 [Available from: http://apps.who.int/ebola/current-situation/ebolasituation-report-30-march-2016 Accessed on 12-42016

24. Centers for Disease Control and Prevention. Cases of Ebola diagnosed in the United States [Available from:

http://www.cdc.gov/vhf/ebola/outbreaks/2014-westafrica/united-states-imported-case.html Accessed on 12-02-2016.

25. Levitz S. Six people from Ebola-affected countries coming to Canada. The Star. 2015 Jan.9, 2015.

26. Mupere E, Kaducu OF, Yoti Z. Ebola haemorrhagic fever among hospitalised children and adolescents in northern Uganda: epidemiologic and clinical observations. Afr Health Sci. 2001; 1(2):60-5.

27. World Health Organization Ebola Response Team. Ebola Virus Disease among Children in West Africa. N Engl J Med 2015; 372:1274-7. doi: 10.1056/NEJMc1415318.

28. Leroy EM, Kumulungui B, Pourrut X, Rouquet P, Hassanin A, Yaba P, et al. Fruit bats as reservoirs of Ebola virus. Nature. 2005; 438(7068):575-6. doi:10.1038/438575a.

29. Pourrut X, Delicat A, Rollin PE, Ksiazek TG, Gonzalez JP, Leroy EM. Spatial and temporal patterns of Zaire ebolavirus antibody prevalence in the possible reservoir bat species. J Infect Dis 2007; 
196 Suppl 2:S176-83. doi: 10.1086/520541.

30. Pourrut X, Souris M, Towner JS, Rollin PE, Nichol ST, Gonzalez J-P, et al. Large serological survey showing cocirculation of Ebola and Marburg viruses in Gabonese bat populations, and a high seroprevalence of both viruses in Rousettus aegyptiacus. BMC Infect Dis. 2009; 9:159. doi : 10.1186/1471-2334-9-159.

31. Feldmann F, Feldmann H. Ebola: facing a new transboundary animal disease? Dev Biol (Basel). 2013; 135:201-9. doi: 10.1159/000190049.

32. Francesconi P, Yoti Z, Declich S, Onek PA, Fabiani $\mathrm{M}$, Olango $\mathrm{J}$, et al. Ebola hemorrhagic fever transmission and risk factors of contacts, Uganda. Emerg Infect Dis. 2003; 9(11):1430-7.

33. Feldmann H, Jones S, Klenk HD, Schnittler HJ. Ebola virus: from discovery to vaccine. Nat Rev Immunol. 2003; 3(8):677-85. doi: 10.1038/nri1154.

34. Roels TH, Bloom AS, Buffington J, Muhungu GL, Mac Kenzie WR, Khan AS, et al. Ebola hemorrhagic fever, Kikwit, Democratic Republic of the Congo, 1995: risk factors for patients without a reported exposure. J Infect Dis. 1999; 179 Suppl 1:S92-7. doi: 10.1086/514286.

35. Regnery RL, Johnson KM, Kiley MP. Virion nucleic acid of Ebola virus. J Virol. 1980; 36(2):465-9. doi: 0022-538X/80/11-0465/05\$02.00/0.

36. Feldmann H, Muhlberger E, Randolf A, Will C, Kiley MP, Sanchez A, et al. Marburg virus, a filovirus: messenger RNAs, gene order, and regulatory elements of the replication cycle. Virus Res. 1992; 24(1):1-19.

37. Sanchez A, Kiley MP, Holloway BP, Auperin DD. Sequence analysis of the Ebola virus genome: organization, genetic elements, and comparison with the genome of Marburg virus. Virus Res. 1993; 29(3):215-40. doi:10.1016/0168-1702(93)90063-S.

38. Feldmann H, Kiley MP. Classification, structure, and replication of filoviruses. Curr Top Microbiol Immunol. 1999; 235:1-21.

39. Muhlberger E, Weik M, Volchkov VE, Klenk HD, Becker S. Comparison of the transcription and replication strategies of marburg virus and Ebola virus by using artificial replication systems. J Virol. 1999; 73(3):2333-42. doi: 0022-538X/99/\$04.0010.

40. Sanchez A, Trappier SG, Mahy BW, Peters CJ, Nichol ST. The virion glycoproteins of Ebola viruses are encoded in two reading frames and are expressed through transcriptional editing. Proc Natl Acad Sci U.S.A. 1996; 93(8):3602-7.

41. Volchkov VE, Becker S, Volchkova VA, Ternovoj VA, Kotov AN, Netesov SV, et al. GP mRNA of Ebola virus is edited by the Ebola virus polymerase and by $\mathrm{T} 7$ and vaccinia virus polymerases. Virol $\mathrm{J}$. 1995; 214(2):421-30. doi:10.1006/viro.1995.0052.

42. Feldmann H, Jaax N, Jahrling P, Klenk HD, Ksiazek
TG, Netesov SV, Peters CJ, Sanchez A, Volchkov VE. Filoviridae study group. In: CM Fauquet, J Maniloff, U Desselberger, LA Ball, editors. Virus Taxonomy: classification and nomenclature of viruses. Eighth Report. California, U.S.A.: Elsevier Academic Press; 2005. p. 618-747.

43. Yang ZY, Duckers HJ, Sullivan NJ, Sanchez A, Nabel EG, Nabel GJ. Identification of the Ebola virus glycoprotein as the main viral determinant of vascular cell cytotoxicity and injury. Nat Med. 2000; 6(8):886-9. doi:10.1038/78654.

44. Jeffers SA, Sanders DA, Sanchez A. Covalent modifications of the ebola virus glycoprotein. J Virol. 2002; 76(24):12463-72. doi: 10.1128/JVI.76.24.12463-12472.2002.

45. Dolnik O, Volchkova V, Garten W, Carbonnelle C, Becker S, Kahnt J, et al. Ectodomain shedding of the glycoprotein GP of Ebola virus. EMBO J. 2004; 23(10):2175-84. doi: 10.1038/sj.emboj.7600219.

46. Gallaher WR. Similar structural models of the transmembrane proteins of Ebola and avian sarcoma viruses. Cell. 1996; 85(4):477-8. doi.org/10.1016/S0092-8674(00)81248-9.

47. Lee JE, Saphire EO. Ebolavirus glycoprotein structure and mechanism of entry. Future Virol. 2009; 4(6):621-35. doi: 10.2217/fvl.09.56.

48. Lucht A, Grunow R, Otterbein C, Moller P, Feldmann H, Becker S. Production of monoclonal antibodies and development of an antigen capture ELISA directed against the envelope glycoprotein GP of Ebola virus. Med Microbiol Immun. 2004; 193(4):181-7. doi:10.1007/s00430-003-0204-z.

49. Kolesnikova L, Bamberg S, Berghofer B, Becker S. The matrix protein of Marburg virus is transported to the plasma membrane along cellular membranes: exploiting the retrograde late endosomal pathway. J Virol. 2004; 78(5):2382-93. doi: 10.1128/JVI.78.5.2382-2393.2004.

50. Ruigrok RW, Schoehn G, Dessen A, Forest E, Volchkov V, Dolnik O, et al. Structural characterization and membrane binding properties of the matrix protein VP40 of Ebola virus. J Mol Biol. 2000; 300(1):103-12. doi.org/10.1006/jmbi.2000.3822.

51. Scianimanico S, Schoehn G, Timmins J, Ruigrok RH, Klenk HD, Weissenhorn W. Membrane association induces a conformational change in the Ebola virus matrix protein. EMBO J. 2000; 19(24):6732-41. doi: 10.1093/emboj/19.24.6732.

52. Gomis-Ruth FX, Dessen A, Timmins J, Bracher A, Kolesnikowa L, Becker S, et al. The matrix protein VP40 from Ebola virus octamerizes into pore-like structures with specific RNA binding properties. Structure. 2003; 11(4):423-33. doi.org/10.1016/S0969-2126(03)00050-9.

53. Timmins J, Schoehn G, Kohlhaas C, Klenk H-D, 
Ruigrok RWH, Weissenhorn W. Oligomerization and polymerization of the filovirus matrix protein VP40. Virol J. 2003; 312(2):359-68. doi:10.1016/S0042-6822(03)00260-5.

54. Licata JM, Johnson RF, Han Z, Harty RN. Contribution of ebola virus glycoprotein, nucleoprotein, and VP24 to budding of VP40 viruslike particles. J Virol. 2004; 78(14):7344-51. doi: 10.1128/JVI.78.14.7344-7351.2004.

55. Soni SP, Stahelin RV. The Ebola virus matrix protein VP40 selectively induces vesiculation from phosphatidylserine-enriched membranes. J Biol Chem. 2014; 289(48):33590-7. doi: 10. 1074 / jbc. M114. 586396.

56. Han Z, Harty RN. Packaging of actin into Ebola virus VLPs. Virol J. 2005; 2:92. doi: 10.1186/1743422X-2-92.

57. Bamberg S, Kolesnikova L, Moller P, Klenk HD, Becker S. VP24 of Marburg virus influences formation of infectious particles. J Virol. 2005; 79(21):13421-33. doi: 10.1128/JVI.79.21.1342113433.2005.

58. Reid SP, Leung LW, Hartman AL, Martinez O, Shaw ML, Carbonnelle C, et al. Ebola virus VP24 binds karyopherin alpha1 and blocks STAT1 nuclear accumulation. J Virol. 2006; 80(11):5156-67. doi: 10.1128/JVI.02349-05.

59. Han Z, Boshra H, Sunyer JO, Zwiers SH, Paragas J, Harty RN. Biochemical and functional characterization of the Ebola virus VP24 protein: implications for a role in virus assembly and budding. J Virol. 2003; 77(3):1793-800. doi: 10.1128/JVI.77.3.1793-1800.2003.

60. Huang Y, Xu L, Sun Y, Nabel GJ. The assembly of Ebola virus nucleocapsid requires virion-associated proteins 35 and 24 and posttranslational modification of nucleoprotein. Mol Cell. 2002; 10(2):307-16. doi: 10.1016/S1097-2765(02)005889.

61. Kiley MP, Regnery RL, Johnson KM. Ebola virus: identification of virion structural proteins. J Gen Virol. 1980; 49(2):333-41. doi: 10.1099/0022-131749-2-333.

62. Ali MT, Islam MO. A Highly Conserved GEQYQQLR Epitope Has Been Identified in the Nucleoprotein of Ebola Virus by Using an In Silico Approach. Adv Bioinformatics. 2015; 2015:278197. doi:10.1155/2015/278197.

63. Becker S, Rinne C, Hofsass U, Klenk HD, Muhlberger E. Interactions of Marburg virus nucleocapsid proteins. Virol J. 1998; 249(2):406-17. doi: 10.1006/viro.1998.9328.

64. Bale S, Julien JP, Bornholdt ZA, Kimberlin CR, Halfmann P, Zandonatti MA, et al. Marburg virus VP35 can both fully coat the backbone and cap the ends of dsRNA for interferon antagonism. PLoS
Pathog. 2012; 8(9):e1002916. doi:10.1371/journal.ppat.1002916.

65. Modrof J, Becker S, Muhlberger E. Ebola virus transcription activator VP30 is a zinc-binding protein. J Virol. 2003; 77(5):3334-3338. doi: 10.1128/JVI.77.5.3334-3338.2003.

66. Hartlieb B, Modrof J, Muhlberger E, Klenk HD, Becker S. Oligomerization of Ebola virus VP30 is essential for viral transcription and can be inhibited by a synthetic peptide. J Biol Chem. 2003; 278(43):41830-6. doi: 10.1074/jbc.M307036200.

67. Muhlberger E, Sanchez A, Randolf A, Will C, Kiley MP, Klenk HD, et al. The nucleotide sequence of the L gene of Marburg virus, a filovirus: homologies with paramyxoviruses and rhabdoviruses. Virol J. 1992; 187(2):534-547.

68. Geisbert TW, Hensley LE, Larsen T, Young HA, Reed DS, Geisbert JB, et al. Pathogenesis of Ebola hemorrhagic fever in cynomolgus macaques: evidence that dendritic cells are early and sustained targets of infection. Am J Pathol. 2003; 163(6):2347-70. doi: 10.1016/S00029440(10)63591-2.

69. Jin HL, Yan ZP, Prabhakar BS, Feng ZD, Ma YJ, Verpooten D, et al. The VP35 protein of Ebola virus impairs dendritic cell maturation induced by virus and lipopolysaccharide. J Gen Virol. 2010; 91:35261. doi: 10.1099/vir.0.017343-0.

70. Baize S, Leroy EM, Georges AJ, Georges-Courbot MC, Capron M, Bedjabaga I, et al. Inflammatory responses in Ebola virus-infected patients. Clin Exp Immunol. 2002; 128(1):163-8. doi: 10.1046/j.13652249.2002.01800.x.

71. Sanchez A, Lukwiya M, Bausch D, Mahanty S, Sanchez AJ, Wagoner KD, et al. Analysis of human peripheral blood samples from fatal and nonfatal cases of Ebola (Sudan) hemorrhagic fever: cellular responses, virus load, and nitric oxide levels. J Virol. 2004; 78(19):10370-7. doi: 10.1128/JVI.78.19.10370-10377.2004.

72. Bavari S, Bosio CM, Wiegand E, Ruthel G, Will AB, Geisbert TW, et al. Lipid raft microdomains: a gateway for compartmentalized trafficking of Ebola and Marburg viruses. J Exp Med. 2002; 195(5):593602. doi: 10.1084/jem.20011500.

73. Chertow DS, Kleine C, Edwards JK, Scaini R, Giuliani R, Sprecher A. Ebola virus disease in West Africa--clinical manifestations and management. N Engl J Med. 2014; 371(22):2054-7. doi: 10.1056/NEJMp1413084.

74. World Health Organization. Ebola virus disease [Available from: http://www.who.int/mediacentre/factsheets/fs103/en/ Accessed on 10-08-2016.

75. Leroy EM, Baize S, Volchkov VE, Fisher-Hoch SP, Georges-Courbot MC, Lansoud-Soukate J, et al. 
Human asymptomatic Ebola infection and strong inflammatory response. Lancet. 2000; 355(9222):2210-5. doi: 10.1016/S01406736(00)02405-3

76. Baxter AG. Symptomless infection with Ebola virus. Lancet (London, England). 2000;355(9222):2178-9.

77. Leroy EM, Baize S, Volchkov VE, Fisher-Hoch SP, Georges-Courbot MC, Lansoud-Soukate J, et al. Human asymptomatic Ebola infection and strong inflammatory response. Lancet. 2000; 355(9222):2210-5. doi: 10.1016/S01406736(00)02405-3.

78. Mabey D, Peeling RW, Ustianowski A, Perkins MD. Diagnostics for the developing world. Nat Rev Microbiol. 2004; 2(3):231-40. doi: 10.1021/ac9013989

79. Ellis DS, Stamford S, Lloyd G, Bowen ET, Platt GS, Way H, et al. Ebola and Marburg viruses: I. Some ultrastructural differences between strains when grown in Vero cells. J Med Virol. 1979; 4(3):201211.

80. Duc JL. Requirements for and challenges associated with BSL-4 labs (Plenary session) 8. Washington (DC: Committee on Anticipating Biosecurity Challenges of the Global Expansion of HighContainment Biological Laboratories; National Academy of Sciences; National Research Council. Biosecurity Challenges of the Global Expansion of High-Containment Biological Laboratories. National Academies Press (US); 2011.

81. Yanik AA, Huang M, Kamohara O, Artar A, Geisbert TW, Connor JH, et al. An optofluidic nanoplasmonic biosensor for direct detection of live viruses from biological media. Nano letters. 2010; 10(12):4962-9. doi: 10.1021/nl103025u.

82. Daaboul GG, Lopez CA, Chinnala J, Goldberg BB, Connor JH, Unlu MS. Digital sensing and sizing of vesicular stomatitis virus pseudotypes in complex media: a model for Ebola and Marburg detection. ACS Nano. 2014; 8(6):6047-55. doi: 10.1021/nn501312q.

83. Drosten C, Panning M, Guenther S, Schmitz H. False-negative results of PCR assay with plasma of patients with severe viral hemorrhagic fever. J Clin Microbiol. 2002; 40(11):4394-5. doi: 10.1128/JCM.40.11.4394-4395.2002.

84. Sanchez A, Ksiazek TG, Rollin PE, Miranda ME, Trappier SG, Khan AS, et al. Detection and molecular characterization of Ebola viruses causing disease in human and nonhuman primates. J Infect Dis. 1999; 179 Suppl 1:S164-9. doi: 10.1086/514282.

85. Gibb TR, Norwood DA, Jr., Woollen N, Henchal EA. Development and evaluation of a fluorogenic $5^{\prime}$ nuclease assay to detect and differentiate between Ebola virus subtypes Zaire and Sudan. J Clin
Microbiol. 2001; 39(11):4125-30. doi: 10.1128/JCM.39.11.4125-4130.2001

86. Drosten C, Gottig S, Schilling S, Asper M, Panning $\mathrm{M}$, Schmitz $\mathrm{H}$, et al. Rapid detection and quantification of RNA of Ebola and Marburg viruses, Lassa virus, Crimean-Congo hemorrhagic fever virus, Rift Valley fever virus, dengue virus, and yellow fever virus by real-time reverse transcription-PCR. J Clin Microbiol. 2002; 40(7):2323-30. doi: 10.1128/JCM.40.7.23232330.2002.

87. Liu Y, Shi ZX, Ma YK, Wang HT, Wang ZY, Shao $\mathrm{DH}$, et al. Development of SYBR Green I real-time RT-PCR for the detection of Ebola virus. Bing du xue bao $=$ Chinese J Virol. [bian ji, Bing du xue bao bian ji wei yuan hui]. 2012; 28(5):567-71.

88. Huang Y, Wei H, Wang Y, Shi Z, Raoul H, Yuan Z. Rapid detection of filoviruses by real-time TaqMan polymerase chain reaction assays. Virol Sin. 2012; 27(5):273-7. doi: 10.1007/s12250-012-3252-y.

89. McKinney MD, Moon SJ, Kulesh DA, Larsen T, Schoepp RJ. Detection of viral RNA from paraffinembedded tissues after prolonged formalin fixation. J Clin Virol. 2009; 44(1):39-42. doi: 10.1016/j.jcv.2008.09.003.

90. Strecker T, Palyi B, Ellerbrok H, Jonckheere S, de Clerck H, Bore JA, et al. Field Evaluation of Capillary Blood Samples as a Collection Specimen for the Rapid Diagnosis of Ebola Virus Infection During an Outbreak Emergency. Clin Infect Dis. 2015; 61(5):669-75. doi: 10.1093/cid/civ397.

91. Kurosaki Y, Takada A, Ebihara H, Grolla A, Kamo N, Feldmann H, et al. Rapid and simple detection of Ebola virus by reverse transcription-loop-mediated isothermal amplification. J Virol Met. 2007; 141(1):78-83. doi: 10.1016/j.jviromet.2006.11.031.

92. $\mathrm{Li} \mathrm{Y}, \mathrm{Cu}$ YT, Luo D. Multiplexed detection of pathogen DNA with DNA-based fluorescence nanobarcodes. Nat Biotechnol. 2005; 23(7):885-9. doi:10.1038/nbt1106.

93. Formenty P, Leroy EM, Epelboin A, Libama F, Lenzi M, Sudeck H, et al. Detection of Ebola virus in oral fluid specimens during outbreaks of Ebola virus hemorrhagic fever in the Republic of Congo. Clin Infect Dis. 2006; 42(11):1521-6. doi: 10.1086/503836.

94. Elliott LH, Kiley MP, McCormick JB. Descriptive analysis of Ebola virus proteins. Virol J. 1985; 147(1):169-76. doi:10.1016/0042-6822(85)90236-3.

95. Kallstrom G, Warfield KL, Swenson DL, Mort S, Panchal RG, Ruthel G, et al. Analysis of Ebola virus and VLP release using an immunocapture assay. $\mathrm{J}$ Virol Methods. 2005; 127(1):1-9. doi: 10.1016/j.jviromet.2005.02.015.

96. Broadhurst MJ, Kelly JD, Miller A, Semper A, Bailey D, Groppelli E, et al. ReEBOV Antigen 
Rapid Test kit for point-of-care and laboratory-based testing for Ebola virus disease: a field validation study. Lancet. 2015; 386(9996):867-74. doi: 10.1016/S0140-6736(15)61042-X.

97. Ikegami T, Niikura M, Saijo M, Miranda ME, Calaor AB, Hernandez M, et al. Antigen capture enzyme-linked immunosorbent assay for specific detection of Reston Ebola virus nucleoprotein. Clin Diagn Lab Immunol. 2003; 10(4):552-7.

98. Yu JS, Liao HX, Gerdon AE, Huffman B, Scearce RM, McAdams M, et al. Detection of Ebola virus envelope using monoclonal and polyclonal antibodies in ELISA, surface plasmon resonance and a quartz crystal microbalance immunosensor. J Virol Methods. 2006; 137(2):219-28. doi: 10. 1016 / j. j viromet. 2006. 06.014.

99. Yen CW, de Puig H, Tam JO, Gomez-Marquez J, Bosch I, Hamad-Schifferli K, et al. Multicolored silver nanoparticles for multiplexed disease diagnostics: distinguishing dengue, yellow fever, and Ebola viruses. Lab Chip. 2015; 15(7):16381641. doi: 10.1039/c5lc00055f.

100.Lucht A, Formenty P, Feldmann H, Gotz M, Leroy E, Bataboukila P, et al. Development of an immunofiltration-based antigen-detection assay for rapid diagnosis of Ebola virus infection. J Infect Dis. 2007; 196 Suppl 2:S184-92. doi: 10.1086/520593.

101.Duan D, Fan K, Zhang D, Tan S, Liang M, Liu Y, et al. Nanozyme-strip for rapid local diagnosis of Ebola. Biosens Bioelectron. 2015; 74:134-41. doi: 10.1016/j.bios.2015.05.025.

102. Miethe P, Gary D, Hlawatsch N, Gad A-M. Rapid detection of EBOLA VP40 in microchip immunofiltration assay. SPIE. 2015; 9490E.0HM. doi: $10.1117 / 12.2184649$.

103. Sherwood LJ, Hayhurst A. Ebolavirus nucleoprotein C-termini potently attract single domain antibodies enabling monoclonal affinity reagent sandwich assay (MARSA) formulation. PloS one. 2013; 8(4):e61232. doi: 10.1371/journal.pone.0061232.

104.Changula K, Yoshida R, Noyori O, Marzi A, Miyamoto $\mathrm{H}$, Ishijima $\mathrm{M}$, et al. Mapping of conserved and species-specific antibody epitopes on the Ebola virus nucleoprotein. Virus Res. 2013; 176(1-2):83-90. doi: 10.1016/j.virusres.2013.05.004.

105.Ksiazek TG, West CP, Rollin PE, Jahrling PB, Peters CJ. ELISA for the detection of antibodies to Ebola viruses. J Infect Dis. 1999; 179 Suppl 1:S1928. doi: 10.1086/514313.

106.Prehaud C, Hellebrand E, Coudrier D, Volchkov VE, Volchkova VA, Feldmann $\mathrm{H}$, et al. Recombinant Ebola virus nucleoprotein and glycoprotein (Gabon 94 strain) provide new tools for the detection of human infections. J Gen Virol. 1998; 79(Pt 11):2565-72. doi: 10.1099/0022-131779-11-2565.
107.Ikegami T, Saijo M, Niikura M, Miranda MEG, Calaor AB, Hernandez M, et al. Development of an immunofluorescence method for the detection of antibodies to Ebola virus subtype Reston by the use of recombinant nucleoprotein-expressing $\mathrm{HeLa}$ cells. Microbiol Immunol. 2002; 46(9):633-8. doi: 10.1111/j. 1348-0421.2002.tb02745.x.

108. Saijo M, Niikura M, Morikawa S, Ksiazek TG, Meyer RF, Peters CJ, et al. Enzyme-linked immunosorbent assays for detection of antibodies to Ebola and Marburg viruses using recombinant nucleoproteins. J Clin Microbiol. 2001; 39(1):1-7. doi: 10.1128/JCM.39.1.1-7.2001.

109. Nakayama E, Yokoyama A, Miyamoto H, Igarashi M, Kishida N, Matsuno K, et al. Enzyme-linked immunosorbent assay for detection of filovirus species-specific antibodies. Clin Vaccine Immunol. 2010; 17(11):1723-8. doi: 10.1128/CVI.00170-10.

110. Onyango CO, Opoka ML, Ksiazek TG, Formenty P, Ahmed A, Tukei PM, et al. Laboratory diagnosis of Ebola hemorrhagic fever during an outbreak in Yambio, Sudan, 2004. J Infect Dis. 2007; 196 Suppl 2:S193-8. doi: 10.1086/520609.

111.Pardee K, Green AA, Ferrante T, Cameron DE, DaleyKeyser A, Yin P, et al. Paper-based synthetic gene networks. Cell. 2014; 159(4):940-54.

112. Ksiazek TG, Rollin PE, Jahrling PB, Johnson E, Dalgard DW, Peters CJ. Enzyme immunosorbent assay for Ebola virus antigens in tissues of infected primates. J Clin Microbiol. 1992; 30(4):947-50. doi: 10.1016/j.cell.2014.10.004.

113.Pain C, Dumont J, Dumoulin M. Camelid singledomain antibody fragments: Uses and prospects to investigate protein misfolding and aggregation, and to treat diseases associated with these phenomena. Biochimie. 2015; 111:82-106. doi: 10.1016/j.biochi.2015.01.012.

114.Gaylord ST, Dinh TL, Goldman ER, Anderson GP, Ngan KC, Walt DR. Ultrasensitive Detection of Ricin Toxin in Multiple Sample Matrixes Using Single-Domain Antibodies. Anal Chem. 2015; 87(13):6570-7. doi: 10.1021/acs.analchem.5b00322.

115.Siontorou CG. Nanobodies as novel agents for disease diagnosis and therapy. Int $\mathrm{J}$ Nanomedicine. 2013; 8:4215-27. doi: 10.2147/IJN.S39428.

116. Sunwoo HH, Nakano T, Dixon WT, Sim JS. Immune responses in chickens against lipopolysaccharide of Escherichia coli and Salmonella typhimurium. Poult Sci. 1996; 75(3):342-5.

117. Schade R, Hlinak A. Egg Yolk Antibodies, State of the Art and Future Prospects. ALTEX. 1996; 13(5):5-9.

118. Akita EM, Nakai S. Immunoglobulins from EggYolk - Isolation and Purification. J Food Sci. 1992; 57(3):629-34. doi: $\quad$ 10.1111/j.1365- 
2621.1992.tb08058.x.

119. Shimizu M, Nagashima H, Sano K, Hashimoto K, Ozeki M, Tsuda K, et al. Molecular stability of chicken and rabbit immunoglobulin G. Biosci. Biotechnol. Biochem 1992; 56(2):270-4.

120.Palaniyappan A, Das D, Kammila S, Suresh MR, Sunwoo HH. Diagnostics of severe acute respiratory syndrome-associated coronavirus (SARS-CoV) nucleocapsid antigen using chicken immunoglobulin Y. Poult Sci. 2012; 91(3):636-42. doi: 10.3382/ps.2011-01916.

121.Alessandro R, Gallo A, Barranca M, Principe S, Taverna S, Duro G, et al. Production of an egg yolk antibody against Parietaria judaica 2 allergen. Poult Sci 2009; 88(8):1773-8. doi: 10.3382/ps.200900054.

122. Silva Ados S, Vasconcelos GA, Kappel LA, Pinto MA, Paula VS. An immunoenzymatic assay for the diagnosis of hepatitis A utilising immunoglobulin Y. Memorias do Instituto Oswaldo Cruz. 2012; 107(7):960-3.

123. Nie G, Wang T, Lu S, Liu W, Li Y, Lei J. Detection of Clonorchis sinensis circulating antigen in sera from Chinese patients by immunomagnetic bead ELISA based on IgY. PloS one. 2014; 9(12):e113208. doi: 10.1371/journal.pone.0113208.

124.Liu LN, Jing FJ, Cui J, Fu GY, Wang ZQ. Detection of circulating antigen in serum of mice infected with Trichinella spiralis by an IgY-IgM mAb sandwich ELISA. Exp Parasitol. 2013; 133(2):150-5. doi: 10.1016/j.exppara.2012.11.001.

125.Lupicka-Slowik A, Walczak M, Grzywa R, Bobrek $\mathrm{K}$, Lecka M, Boivin S, et al. Generation and application of polyclonal IgY antibodies specific for full-length and nicked prostate-specific antigen. Bioanalysis. 2014; 6(23):3197-213. doi: 10.4155/bio.14.172.

126. Suresh MR, Cuello AC, Milstein C. Bispecific monoclonal antibodies from hybrid hybridomas.
Methods Enzymol. 1986; 121:210-28.

127. Milstein C, Cuello AC. Hybrid hybridomas and their use in immunohistochemistry. Nature. 1983; 305(5934):537-40. doi: 10.1038/305537a0.

128. Kreutz FT, Suresh MR. Novel bispecific immunoprobe for rapid and sensitive detection of prostate-specific antigen. Clin Chem. 1997; 43(4):649-56.

129. Byrne H, Conroy PJ, Whisstock JC, O'Kennedy RJ. A tale of two specificities: bispecific antibodies for therapeutic and diagnostic applications. Trends Biotechnol. 2013; 31(11):621-32. doi: 10.1016/j.tibtech.2013.08.007.

130. Ganguly A, Malabadi RB, Loebenberg R, Suresh MR, Sunwoo HH. Heterosandwich immunoswab assay for Dengue virus Ns1 antigen detection. Diag. Mircobiol Infect Dis. 2014; 78(1): 35-9.

131.Parashar A, Sarkar S, Ganguly A, Sharma SK, Suresh MR. Bispecific antibodies for diagnostic applications. Bispecific Antibodies. Springer Berlin Heidelberg. Ed. Roland Kontermann. 2011; 349367.

132.Luo H, Hong H, Yang SP, Cai W. Design and applications of bispecific heterodimers: molecular imaging and beyond. Mol Pharm. 2014; 11(6):175061. doi: $10.1021 / \mathrm{mp} 500115 \mathrm{x}$.

133. Qiu X, Wong G, Audet J, Bello A, Fernando L, Alimonti JB, Fausther-Bovendo H, Wei H, Aviles J, Hiatt E, Johnson A, Morton J, et al. Reversion of advanced Ebola virus disease in nonhuman primates with ZMapp. Nature. 2014; 514(7520):47-53. doi: 10.1038/nature13777.

134. Qiu X, Audet J, Lv M, he S, Wong G, Wei H, Luo L, Fernando L, Kroeker A, Fausther-Bovendo H, Bello A, et al. Two-mAb cocktail protects macaques against the Makona variant of Ebola virus. Sci Transl Med. 2016; 8(329):329ra33. doi: 10.1126/scitranslmed.aad 9875 . 